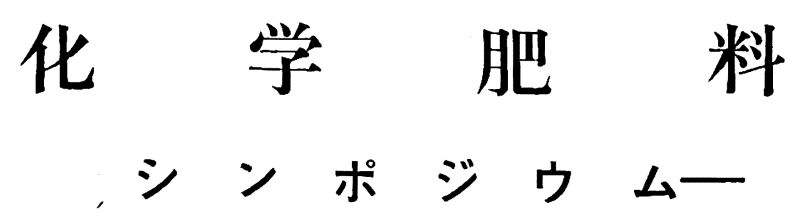

最近血硫酸根肥料の要望が高まり, 肥料工業合理化の動きと相侯って, 窒素肥料では尿素, 塩安, 硝安, リン 酸肥料では溶成リン肥, 焼成リン肥, 湿式リン酸が多量に生産されるよ5になった。一方硫安, 過リン酸石灰の 製造にも多くの改良や研究がなされ，肥料工業も大きく变貌するとともに多くの問題を含んでいる。

本シンポジウムでは，これら化学肥料の諸問題について有益な参考になることを目的として，工学，工業およ 心゙佺業の立場からの総説を载せた。また従来製造会社の研究がほとんど公表されていないので，主要な問題につ いて会社からの研究報告を載せることを主腿として多数の社に依頼して 8 社から報文をいたたき，これに一般投 稿中の報文を加えた。

この企画、編集には安藤淳平氏の御尽力をえたことを付記して感謝の意を表します。

工業化学雑誌編集委員長岡

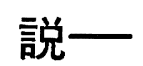

\title{
化学肥料，主としてリン酸肥料について
}

\section{1) 前}

今回化学肥料関するシンポジゥムが試みられるに当って,リ ン酸肥料注いて書くょ5に割り当てられたので，次にリン酸肥 料関する 2,3 の問題点について述べて見よ5。

化学杷料の第 1 要素あるいは 3 大要素としての窒素 $\left(\mathrm{N}_{2}\right)$, リ ン酸 $\left(\mathrm{P}_{2} \mathrm{O}_{5}\right)$ ，カリ $\left(\mathrm{K}_{2} \mathrm{O}\right)$ の施用量は世界合計でおのおの年約 650 〜7507jトン位ずつで, 窒素分 100 に対しリン酸分は約 100 位,カ リ分は約 90 位であることは，次の表 1 に示すよ5になり，5〜6 作前までのリン酸分 130〜150，カリ分 100〜110 位であったもの が，窒素の增加が特に多かったためであるが，3肥料要素ともに 著しく增加し（第 2 次世界大戦終了直後の 1946〜1947 年は大戦 直前の 1939 年の $74 \sim 92 \%$ まで减少したものが), 3 年目 (1948 年）には指数 109 末で回復し，以後 10 年間に 2 倍以上（指数 216〜238）にまで增加して来，またりン酸肥料はほとんど窒素肥 料と同類となり，カリ肥料がやや少なく（指数 88），約 90\% 以 下になっている。

これを世界の 6 大陸別にその使用割合を見ると次の表 2 のよ5 に窒素, リン酸, カリともにヨーロッパが第 1 , 北アメリカが第 表 1 世界の窒装, リン酸, カリの 3 肥料要素の生産高

(単位 1000 トン)

\begin{tabular}{|c|c|c|c|c|c|c|c|c|}
\hline \multirow{2}{*}{ 竹次 } & \multicolumn{2}{|c|}{ 祸 } & \multicolumn{2}{|c|}{ リン酸 } & \multicolumn{2}{|r|}{ リ } & \multirow{2}{*}{ 合計 } & \multirow{2}{*}{$\begin{array}{l}\text { 1939年 } \\
\text { を } 100 \\
\text { とし }\end{array}$} \\
\hline & 牛倩酒 & 指数 & 牛这宫 & 指数 & 生橉高 & 指数 & & \\
\hline 1939 & 2,596 & 100 & 3,554 & 137 & 2,789 & 107 & 8,939 & 100 \\
\hline 1946 & 1,850 & $" \prime$ & 2,750 & 148 & 2,000 & 109 & 6,600 & 74 \\
\hline 1947 & 2,382 & " & 3,916 & 164 & 2,377 & 100 & 8,213 & 92 \\
\hline 1948 & 2,918 & $"$ & 4,656 & 160 & 2,804 & $\Rightarrow \quad 96$ & 9,810 & 109 \\
\hline 1950 & 3,590 & $"$ & 5,417 & 151 & 3,791 & 105 & 12,798 & 143 \\
\hline 1952 & 4,462 & $"$ & 5,968 & 134 & 4,938 & 110 & 15,368 & 172 \\
\hline 1954 & 5,570 & " & 6,389 & 115 & 5,733 & 103 & 17,692 & 198 \\
\hline 1955 & 6,225 & $" \prime$ & 6,879 & 110 & 6,120 & 99 & 19,230 & 216 \\
\hline 1956 & 6,760 & $" \prime$ & 7,187 & 106 & 6,283 & 93 & 20,220 & 227 \\
\hline 1957 & 7,422 & $" \prime$ & 7,436 & 100 & 6,501 & 88 & 21,359 & 238 \\
\hline
\end{tabular}

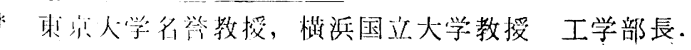

\section{永 \# 彰 一 郎*}

表 2 大陸別の窒素, リン酸, カリの 3 肥料要素の使用率 (\%)

\begin{tabular}{|c|c|c|c|c|c|c|c|c|c|c|c|c|}
\hline 年次 & & & & & 1955 & & & 1956 & & & 1957 & \\
\hline 別一等 & $\mathbf{N}$ & $\mathbf{P}$ & $\mathbf{K}$ & $\mathbf{N}$ & $\mathbf{P}$ & $\mathbf{K}$ & $\mathbf{N}$ & $\mathbf{P}$ & $\mathbf{K}$ & $\mathbf{N}$ & $\mathbf{P}$ & $\mathbf{K}$ \\
\hline ヨーロッパ & 51 & 46 & 72 & 50 & 47 & 73 & 50 & 47 & 72 & 51 & 47 & 73 \\
\hline 北アメリカ & 31 & 37 & 28 & 32 & 35 & 27 & 33 & 26 & 28 & 33 & 32 & 27 \\
\hline 南アメリカ & 5 & 1 & - & 6 & 1 & - & 4 & 1 & - & 4 & 1 & - \\
\hline ア $シ ゙$ & 13 & 5 & - & 12 & 5 & - & 12 & 6 & - & 12 & 7 & - \\
\hline $\boldsymbol{ア} フ$ リカ & - & 3 & - & - & 2 & - & - & 3 & - & - & 3 & - \\
\hline 大洋 州 & - & 8 & - & 一 & 9 & - & - & 9 & - & - & 10 & - \\
\hline
\end{tabular}

2位であることには変わりがないが，カリ肥料は 72～73\%のよ うに大部分をヨーロッパで使用し，また第 3 位は窒素ではアジ ア, リン酸では大洋州であることはアジアの米産に窒素, オース トラリアの麦産にリン酸が多く使用されることを示しているが, 第 5 位は南アメリカの窒素, アフリカは第 6 位としてわずかにリ ン酸肥料の少量が使用されているだけである。

かように，ヨーロッパと北アメリカとに化学肥料使用が大部分 集結するのは人口が稠密のため多施肥多収穫の集約農業の必要上 から化学肥料の多量使用, 従って大量の化学肥料の製造が化学工 業技術の発達とともに達成されているわけである。

\section{2）化学肥料の形態}

上述のよ5に, 化学肥料は大体化学肥料工業の生産ではある が，窒素，リン酸，カリの 3 要素によって大分その括むむきを異 にしており，特にカリ肥料は塩化カリ（KCl）を第 1 とし，硫酸 カリ $\left(\mathrm{K}_{2} \mathrm{SO}_{4}\right)$ がこれにつぎ，その大部分はヨーロッパ大陸，こ とに西ドイッ，東ドイッ，フランスなどの岩塩産地に産出する各 種カリ複塩からと, 近年アメリカのカリ塩の増産が大きいるので あるが，いずれも地下カリ資源の採掘と, その溶出, 分離, 精製 操作を主とする無機塩類化学であり, その他カン水, 海水などか らの裴塩に付随するものも大同小異の精製操作によるカリ塩の製 出によるものと見て差支えない。

窒素肥料は前世紀から今世紀初め, 第 1 次世界大戦までは南米 
チリのチリ硝石の窒素肥料としての地位が最も大きいもので, 従 ってその原鉱のカリチェ (Caliche), コストラ (Costra) なぞか ら共存する他の多くの無機塩類からの分離, 精製により 95〜96\% 以上のチリ硝石 $\left(\mathrm{NaNO}_{3}\right)$ が過半は窒素肥料（窒素約 $15.5 \sim 16 \%$ 含有）とし，残る約 $1 / 3$ 位が硝酸の製造を主とし，少量は各種硝 酸塩としての工業薬品として使用され, 最も盛大な産出の今世紀 初めはチリ硝石の年産は約 200〜250 万トン，窒素として約 35〜 40 方トンを超えたが，その後次第に生産が鈍り，最近では窒素 として約 20 万トン前後であり, 他の合成窒素が前述の 750 万卜 ンにすなったので, チリ硝石の窒素は全窒素の僅か $3 \sim 4 \%$ 位と なり昔日の影はない。

それだけにこの年産 750 万トンの窒素肥料は空中窒素の固定 方式により硫安, 硝安, 塩安などのアンモニウム塩, 近来はアメ リカに盛んなアンモニア単独で施肥することが多くなり，更に尿 素単独またはその塩類（複塩む加えて）が增大し, 硫安とならん でいた石灰窒素は近年その増産がとまり使用量が城じて来た。

かよ5に, 窒素肥料は空中窒素固定に立脚した大化学肥料工業 として確立しているのに対し, リン酸肥料はカリ肥料, 窒素肥料 の中間を行く形態とも考号られ，すなわち原料はほとんど天然産. 地下資源としてのリン釷石に仰ぎ，これ硫酸を作用して過りン 酸石灰としたものが全リン酸肥料の約 80〜 85\% 以上を占め, 単 味をたは配合, 複合肥料として施用され, 近年硫酸の一部を硝 酸, リン酸などにして硫硝リン, 重過リン酸, 硫リン安などの各 、種含リン酸高度肥料の製造が多く，更にこれらのいずれる酸液処 理による湿式製造法汶対して, トーマスリン肥,レナニアリン肥, テトラリン肥, シリコホス(シリコリン肥), レヒリングリン肥, サーモホス(サーモリン肥)などからわが国の溶成りン肥, 烧成り ン肥などにいたるまでの乾式製造法によるものが数多くある。こ れら湿式, 畭式いずれの方法すリン鉱石を主体として相当の化学 操作を加えられた化学肥料であるがカリ肥料についてはその資源 がドイッ,フランス,アメリカなどで岩塩, 地下カン水などに伴わ れて産出，製造された塩化カリ，硫酸カリなどのカリ塩をわが国 などでは年々 70〜80 万トン以上輸入して単味または多くは配合 肥料，一部複合肥料として使用されるだけで，国内資源によるカ り塩またはカリ肥料の製造は製塩に因む苦汁カリ塩, カーナライ 卜，カリ肥料塩（カリ分 $\mathrm{K}_{2} \mathrm{O}$ として約 $30 \sim 35 \%$ のもの), 海藻 灰からョード（沃土）とともに製出されるカリ塩などはきわめて 微々たるもので，カリ塩 $\left(\mathrm{KCl}, \mathrm{K}_{2} \mathrm{SO}_{4}\right)$ としても年約 6,000〜 7,000 トン位で； 70 80 万トンの輸入塩に対して 1\% にる及ば 媇である。国産カリ鉱石 (カリ石英粗面岩が最も有望, カリ長 石は筧業陶磁器, ガラスなどに主に用いられ, カリミョウバン石 はミョウバン, 硫酸アルミニウム製造用) からのカリ塩, カリ肥 料塩の製出は戦時中から筆者らも研究試験し, 最近も東京工業試 験所鈴木等氏らの工業化試駼研究1)があり, また鉄ミョウバン石 （ジャロサイト，Jarosite）の利用についても同氏らの試験研究2) などがあるが，上述の上5に 70〜80 万トンもの安いカリ塩が白 由に輸入される現状ではどうしても国産カリ鉱石からのカリ塩, カリ肥料製出が実現し得ないのは第 1 次世界大戦前後, 次の第 2 次大戦前後, 最近の状態など何度くり返しても実現に達しないの は, 農産確保々国産愛用, 輸入抑制のいずれが先行ないし第 1 に するかの観点に立脚して成立するもののよ5である。

最近の日本の化学肥料の形態の变化を見ると次の表 3 の昭和
表 3 最近 5 力年間の化学肥料增加率

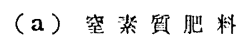

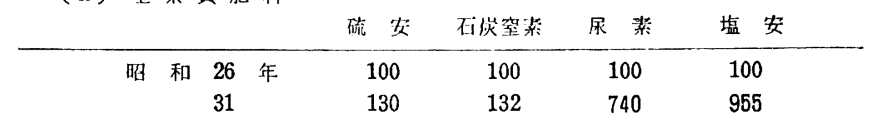

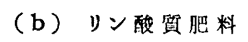

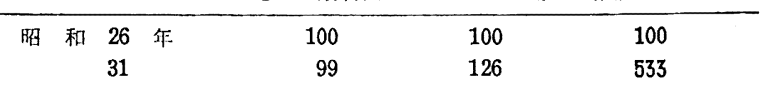

（c）カリ質肥料，その他

\begin{tabular}{ccccc} 
& 硫酸カリ & 壏化カリ & ケイ酸䆩肥料 \\
\hline 昭 和 26 年 & 100 & 100 & 100 \\
& 31 & 118 & 590 & 1,360
\end{tabular}

26 年から昭和 31 年の 5 カ年間でも顕著な变化が認められる。こ れで見るよ5に窒素肥料中の尿素と塩安, リン肥料中の溶成リン 肥, カリ肥料中の塩化カリの 4 種がいずれも昭和 $26 \sim 31$ 年の 5 年間に比率 $533 \sim 955$ (5.3 9.6 倍) と急增加しているのに，そ の他の硫安, 石窒, 過 リン酸, 硫酸カリなどの旧来の主要肥料が 僅かに 18〜32\% 增（過リン酸はほとんど増減なし）と対比して きわめて著しい躍進はこれら 4 種が新肥料であるという点だけで はなく，もっぱら考えられることはいずれる硫酸根 $\left(\mathrm{SO}_{4}{ }^{2-}\right)$ を持 たぬものである点である。これは昭和 25,26 年頃から重大視さ れ, 顕著になった水稲の秋落田または秋落水田の稲作の減収の究 明が土壤中の硫酸根の還元（硫酸根還元バクテリア, sulphate reducing bacteria) による稲根の硫化鉄固着による水稲の枯死 により，実に水田の約 10〜15\%，従って米作の $10 \%$ 以上の減収 とい5 々しい問題から耕土培養法の決定, 無硫酸根肥料の製 造, 施肥の奨励によって急速にこれら尿素, 塩安 (この二つの窒 素肥料は外に尿素がアンモニア合成と, その廃ガス炭酸ガスの利 用, 尿素の葉面撒布肥効, その他, 塩安はアンモニアソーダ法の 食塩のソーダ灰への変化率が $70 \%$ 位の低率で 30\% 位の食塩の 回収, 塩素根含有肥料嫌避の緩和一—これが次の塩化カリの急増 にも現われている——どの点も考えられる), 溶成りン肥, 塩化 カリ（これには上記の塩素根含有肥料排撃の緩和）の 4 種が急増 (ことに塩化カリは新肥料でもなくもっぱらこの無硫酸根肥料の 桨励と, 塩素根含有肥料嫌避の緩和と, 更に硫酸カリょりもカリ 分 $\mathrm{K}_{2} \mathrm{O}$ 当り著しく安価で含有率が高い点も買われた）となって 来ている。

更にこの窒素, リン酸, カリの第 1 の 3 要素以外の第 2 の 3 要 素の $\mathrm{CaO}, \mathrm{MgO}, \mathrm{SiO}_{2}$ (石灰, マグネシア, シリカ) の中シリ カ, マグネシアについて, 近年マグネシア欠乏 (苦土欠乏), シ リカ欠乏（ケイ酸欠之）が作物の成育, 従って, 農産上重大とな って来た結果は, マグネシア欠乏, シリカ欠乏土壤へマグネシ ア, シリカ(いずれもク溶性状態のもの) の補給が必要となって, 各種電気炉製鉄, 高炉製鉄のスラグ（主として石灰とシリカとか らなるケイ酸石灰質のものを, ケイカル肥料と称し, 石灰とマグ ネシアとシリカとからなるケイ酸マグネシウム石灰質のものを苦 はケイカル肥料と称し, この 5,6 年来急速に多く使用され, 年 々 40〜50 万トン以上の施用となり，各種の製鉄，合金のスラグ の利用法として高まって来た）の施用が勃與し，この 1360 の指 数（5 年間で 13.6 倍）とい とくにマグネシアと石灰とを同時に施用出来るといら意味で, こ の外ドロマイトを微粉砤した苦土炭カル，ドロマイト焼成後水和 消化した苦上石灰肥料などが従来の石灰石からの炭カル肥料, 石 网肥料に次第に置換して来ている3)。 


\section{3）リン酸肥料の推移}

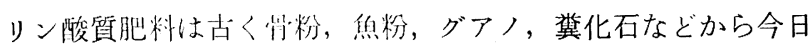
ではもっぱらリン㳘石に集中され，このリン鉣石も大洋源(Ocean origin) のものが大部分で，他はリン不石 (Apatite) 系の火山源 (Volcanic origin) のもの， あるいは前者はグアノ系であるから 有機源リン躬石 (Phosphate rock または Rock phosphate), 後 者を無機源りン鉣 (Phosphate) などとも称しており，フッ素り ン灰石 (Fluor apatite, $3 \mathrm{Ca}_{3}\left(\mathrm{PO}_{4}\right)_{2} \cdot \mathrm{CaF}_{2}$ ) を初めこの $\mathrm{CaF}_{2}$ の ところが $\mathrm{CaF}(\mathrm{OH}), \mathrm{CaFCl}, \mathrm{CaF}\left(\mathrm{HCO}_{3}\right)$ などの形を取り，フ ッ素分が $2 \sim 3 \%$ 位含有するものが多く，過リン酸石灰肥料製造 のときのフッ化水素, フッ化ケイ素発出の原园，これからフッ化 ナトリウム $(\mathrm{NaF})$, 進んでケイフッ化ナトリウム $\left(\mathrm{Na}_{2} \mathrm{SiF}_{6}\right.$, 人 造水晶石, Artificial cryolite) の製出, 各種用途源となる反面, 過りン酸石死杷料のリン酸分の可溶率の良否，更に過りン酸石灰 肥料の眝蔵中扣よび施用後土堎中での水溶性りン酸分の水難溶性 リン酸への戻り（Retrogradation）の原因となるなど幾多の問題 があるため，リン灰石は湿式法の過リン酸石灭の㱔造よりも，乾 式法の溶成リン肥，その他の製造汇向けられることも今日の大增 産のリン鈗不の用途问け，従ってリン酸質肥料の動向にも関係が あるものと考えられる。

今, 世界の全リン鉣石資源の埋蔵量として発表されるものは他 の石炭や，鉄鉣，その他々同様に採掘量の増大にもかかわらず， 調査が進むにつれて，発表の度毎に埋蔵量として発表の数字も増 大して来て扣り，古い（第 2 次世界大戦前）ものでは 170 億トン 位で全世界の年間採掘使用量が 2000 2200 万トン位として約 800 ８50 年分位とされたものが，最近では埋蔵量約 264 億トン の発表で，また年間の採掘使用量が約 3200～3500 万トンでは的 800 年となる。このリン鉣石埋蔵量䄪 264 億トンの中第 1 位はア メリカの 135 億トン $(51 \%)$, ソ連邦の第 2 位的 76 億トン $(29 \%)$, 第 3 位はモロッコ，アルジェリア，チュニスなどの地中海に面し たアフリカのフランス系の約 35 億トン $(13 \%)$ の 3 大産出地域 で，約 246 億トン (93\%)以上，その他の残り $7 \%$ 䄪 18 億トン の中ブラジル (南米) 5.7 億トン (約 $2.2 \%$ ), ヨーロッパ（ソ連 外）全体で約 4.4 億トン（約 1.6\%), 南太平洋のオーシャン, ナウル島およびオーストラリアの約 2.8 億トン (約 $1.1 \%$ ), 入 キシコの約 2.1 億トン (約 $0.8 \%$ ), エジプトの約 1.8 億トン。 (約 $0.6 \%$ ) の小計約 16.8 億トン（約 $6.3 \%$ ) の億単位以下は英 領クリスマス島, 仏領マカテア島などの南太平洋諸島の高品位 $\left(\mathrm{P}_{2} \mathrm{O}_{5}\right.$ で約 $36 \sim 37 \%$ 以上) 富龵も量はいずれも数千万トンの埋 蔵で年々 10 20 万トン台の採㧩がイギリス，オーストラリア， 日本などに向けられている。

さて日本は今次大戦前は南洋委任統領から年約 $20 \sim 30$ 万トン (昭和 11 尔 19.9 万トン, 昭和 12 年 21.8 万トン, 昭和 13 年 29.9 万トン）位の採搔，移入して，これにアメリカ，アフリカ， 南洋の英, 仏領誯島（クリスマス，ナウル，オーシャン，マカテ アなど）からそれぞれ 20〜30 万トンずつ位の輪入との全合計約 100〜120 厅トン位圭使用していたのが，今次第 2 次世界大戦後 はほとんどリン能石の入于が出来なくて，過リン酸石灰の製出高

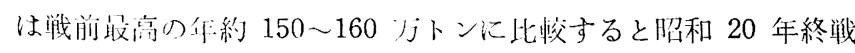
の年には僅かに 100 分の 1 に满た收 1.27 万トン, 翌昭和 21 年 16.8万トンとなった。位糧增座碓绾のため化学肥料第 1 主義によ
ってリン籍石の輸入第一とされ逐年急增して過りン酸石灰は昭和 22 年 70.7 万トン, 昭和 23 年 100.0 万トン, 昭和 24 年 120.0 万トン, 昭和 25 年以来約 $140 \sim 160$ 万トンの戦前の域を越える に至ったのは，もっぱら原料リン鉱石の輸入につき，進駐米国の 援助によりアメリカからの輸入が最大で最近の数年（昭和 29〜 31 年) 間は年約 80〜100 万トンを越え, ついでェジプト，モ口 ッュ，チュニスなどの地中海に面するアフリカ地域から年約 $\mathbf{3 0}$ 〜35 万トン位, 他は南太平洋の仏領マカテア島からの年約 15～17 万トン, 南太平洋諸島からの 8〜10 万トンなどで全体として 135 〜170 万トンのリン鉱石の全部を輸入に仰いでいる以上は最す合 理的な処理法により, 最も有効なりン酸質肥料の製造が最す大切 であり, その肥効的価値を最も十分に出し得る肥料形態の化学肥 料の製造こそ最も重要な点である。従って過去約 140〜150 年の 最も古い強大な勢力のある過リン酸石灭について, 各種の根本的 変化推移を来し, 従来の湿式製法（主として硫酸を作用させる方 法）に対し全く乾式法によってトーマスリン肥, 溶成リン肥, 焼 成リン肥, サーモホス, テトラホス, シリコホス, レナニアリン 肥などの出現はこれら各種の要請, 検討が過リン酸石灰を対象と して行われ，ここに新しい変化推移が見られ，特に過リン酸石扊 のよ5な単味肥料は $2 / 3$ 以下, 他の $1 / 3$ は各種配合または複合肥 料および乾式製法によるものとなって来たが，米国などは更に進 んで $1 / 3$ 以下が単味肥料, $2 / 3$.が配合, 複合肥料で占められて いる。次の表 4 に世界のリン酸質肥料の形態別, 大陸別生産割合 を示した。これで見るよ5に, リン酸分 $\left(\mathrm{P}_{2} \mathrm{O}_{5}\right)$ が低い普通過リン

表 4 リン酸質肥料の形態別, 大陸別製産高の比較 (単位 $\mathrm{P}_{2} \mathrm{O}_{5}$ として 1000 トン)

\begin{tabular}{|c|c|c|c|c|c|c|c|c|c|}
\hline & 年㰠 & $\begin{array}{l}\exists-\square \\
\because \quad ハ 0\end{array}$ & 北米 & 南米 & $T=$ & y & 洲洋 & 合計 & 繤分 \\
\hline \multirow{2}{*}{$\begin{array}{l}\text { 賞通 過 リン酸石 } \\
\text { ( }\left(\mathrm{P}_{2} \mathrm{O}_{5}<25 \% \%\right)\end{array}$} & & 1,531 & 74 & & 306 & 164 & 622 & 05 & 61 \\
\hline & & 1,474 & 1, & & 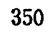 & 174 & 677 & $2 \%$ & \\
\hline \multicolumn{2}{|c|}{ 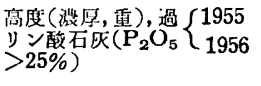 } & & & - & - & 27 & - & 388 & \\
\hline 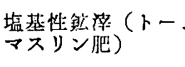 & & & - & - & 8 & - & - & $\begin{array}{l}1,006 \\
1,050\end{array}$ & Al \\
\hline & $\{195$ & 381 & 264 & 72 & 62 & 3 & - & 782 & 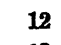 \\
\hline$\tau$ & $\{195$ & 430 & 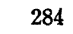 & 74 & 86 & 3 & - & 877 & 10 \\
\hline \multirow{2}{*}{ 位 } & 19 & 3,040 & 2,355 & 80 & 376 & 194 & 622 & 707 & 100 \\
\hline & & 3,120 & 22 & 83 & 443 & 204 & 677 & 944 & 100 \\
\hline \multirow[b]{2}{*}{ 此 巒 \% } & $\{1$ & 45.3 & 35.1 & 1.4 & 5.6 & 3.2 & 9.3 & 100.0 & \\
\hline & & 1.9 & 4.8 & .3 & 6.4 & 3.0 & 9.7 & 100.0 & \\
\hline
\end{tabular}

酸石灰(多くのものは $\mathrm{P}_{2} \mathrm{O}_{5} \quad 18 \sim 20 \%$ 以下で原料リン鉱石の品位 によりその約 $1 / 2$ の\%となる) は全体の 60 位しかない（日本では 80 85\% 以上）有様で，塩基性鉣滓のトーマスリン肥が 15\% を占め，これがヨーロッパだけに特に多いのはドイッ，ルクセン ブルグ，ベルギー，フランスなどの含リン鉄鉱によるトーマス製 鋼法によるものであり, 日本でも最近まで日本鋼管株式会社で年 約 4 万トン $\left(\mathrm{P}_{2} \mathrm{O}_{5}\right.$ 約 $20 \%$ で約 8000 トンの $\mathrm{P}_{2} \mathrm{O}_{5}$ がこの表 4 のア ジアの分）位製造されたが，昨年から純酸素上吹転炉製鋼法に切 换えられてトーマスリン肥の製造は中止となった。 $\mathrm{P}_{2} \mathrm{O}_{5}$ が $25 \%$ 以上（主に 35 38\% 位）の重過りン酸石灰，または $\mathrm{P}_{2} \mathrm{O}_{5}$ が 45 〜 50\% 位の三重過リン酸石灰，これらを総称して高度過 リン䙶 石灰または濃厚過りン酸石灰などといわれるが，アメリカで最も 多く製造され，全体の $12 \sim 13 \%$ (日本では日産化学工業株式会 社で湿式硫酸法リン睖, 日本化学工業株式会社で乾式電気炖リン 扣よびリン酸製造の一部で製造されるが極く少量か中止されてい ることが多いので，この表には出ない）に当たり，これに匹敵す るようにほぼ同量の $12 \sim 13 \%$ ，その他とあるのはドイッのレナ 
ニアリン肥， レヒリングリン肥，アメリカの脱フッリン酸三石 灰，メタリン酸石灰などが主で, 日本の溶成リン肥, 烧成リン肥 などが約 35〜40 万トン位製出されるよ5になって来た。

またこれを大陸別の合計量で見るとヨーロッパの約、45\%，ア メリカの約 35\% で約 $80 \%$ を占め, 大洋洲オーストラリアの $9.5 \%$, アジアの約 $6 \%$ ，アフリカの約 $3 \%$, 南米の約 $1.5 \%$ た らずの順になるが，個々のもので見ると塩基性鉱滓ではヨーロッ パが大部分を占めたり，高級過リン酸石灰ではアメリカが特に多 いような特性はあるが，普通過りン酸石扊ではヨーロッパとアメ リカとがほとんど互角であり，オーストラリアが 15\% 以上であ るなどを見ると，古い普通過りン酸製造法よりも新しい高度のリ ン酸肥料または特殊のトーマスリン肥, 溶成リン肥, レナニアリ ン肥, レヒリングリン肥, 焼成リン肥（この最後のものは前のも のにくらべると最も新しいが，まだ比較になら妙量）などへの 変化移行が見られる。

なおここに日本の窒素, リン酸, カリの 3 要素の化学肥料につ いての最近の生産, 使用高とその比率を最近数年間について表 5 に示そう。これで見ると日本の最近のカリ肥料施用の増加は著し

表 5 本邦化学肥料の生産, 使用高と比率

\begin{tabular}{|c|c|c|c|c|c|c|c|c|}
\hline \multirow{2}{*}{ 年 次 } & \multirow{2}{*}{\multicolumn{2}{|c|}{ 量と比率 }} & \multicolumn{2}{|c|}{ 窒絮質 } & \multicolumn{2}{|c|}{ リン酸質 } & \multirow{2}{*}{$\begin{array}{c}\text { カリ啠 } \\
\text { 内需 }\end{array}$} & \multirow{2}{*}{$\begin{array}{l}\text { 合計 } \\
\text { 内需 }\end{array}$} \\
\hline & & & 生迹 & 内壁 & 生産 & 内需 & & \\
\hline \multirow{2}{*}{ 昭和29年 } & 自位 10 & トン) & 3,027 & 2,447 & 2,295 & 1,987 & 691 & 5,125 \\
\hline & 率 & & 100 & 100 & 100 & 100 & 100 & 100 \\
\hline \multirow{2}{*}{ 昭和 30 年 } & 単位100 & ע) & 3,397 & 2,701 & 2,601 & 2,228 & 789 & 5,718 \\
\hline & 率 & & 112 & 110 & 113 & 112 & 114 & 112 \\
\hline \multirow{2}{*}{ 昭和31年 \{} & （単位100 & トン) & 3,721 & 2,809 & 2,707 & 2,299 & 793 & 5,891 \\
\hline & 率 & & 122 & 114 & 118 & 116 & 114 & 115 \\
\hline \multirow{3}{*}{ 昭和32年 \{} & （単位 100 & トン) & 4,207 & 2,820 & 2,428 & 2,265 & 775 & 5,860 \\
\hline & 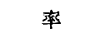 & & 139 & 115 & 105 & 114 & 112 & 114 \\
\hline & 垤 素 & リン酸 & カリ & & & 窒 䒺 & リン酸 & カリ \\
\hline 年 & 100 & 62 & 22 & 昭和 & 31 年 & 100 & 78 & 67 \\
\hline 昭和 26 & 100 & 64 & 34 & 昭和 & 32 年 & 100 & 77 & 66 \\
\hline 昭和 27 & 100 & 61 & 45 & & | 北米 & 100 & 140 & 120 \\
\hline 昭和 28 & 100 & 67 & 65 & & 西独 & 100 & 120 & 10 \\
\hline 昭和 29 & 100 & 77 & 67 & (1955 & 仏 & 100 & 110 & 120 \\
\hline 昭和 30 & 100 & 78 & 69 & & 英 & 100 & 120 & 100 \\
\hline
\end{tabular}

いもので昭和 25 年漸く輸入が増しかけて以来急に多く用いられ, 昭和 $28 \sim 29$ 年以来 $60 \sim 80$ 万トン位の塩化カリ, 硫酸カリ合計 が輸入され使用されて来たので, 窒素肥料の著しい増産にもかか わらず窒素：リン酸：カリ $\left(\mathrm{N}_{2}: \mathrm{P}_{2} \mathrm{O}_{5}: \mathrm{K}_{2} \mathrm{O}\right)$ の割合は戦前の $100: 60: 30$ あたりの小さいものから急 に增して, 昭和 29 年以来 $100: 77 \sim 78$ : 67〜69 位となって来てほとんどリン酸 に近ついて来た。しかし，これを北米， 西独, 英仏と比較するとまだりン酸す少 なく，カリも少なく（これら4 カ国はほ ぼ 100：110１40：100１20であるか ら）リン酸もカリも約 40４5 位少ない。 これはリン鉱石とカリ塩とが全部輸入に 仰いでいることと，日本は水稲米作の窒 素肥料が特に多いため, 窒素 100 の指数 ではこのようになり，欧米の畑作麦，ポ テト作などとの差異をむ考える必要があ ることはもちろんであろう。

\section{4）配合肥料と複合肥料}

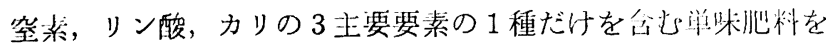

単味に施用することのわずらわしさを少なくするため，2 種また は3 種の単味肥料を適当の割合に混合，唒合したものを沱合肥料 または配合肥料とされているが，各肥料の粉性，中性，塩基性な どの化学性を十分わきまえて配合しないと，この混合後直ちに， または混合後次第に反応を起して, 各肥料成分が遊踓して揮発損 失するもの（たとえば窒素質肥料の窒素分がアンモニア $\mathrm{NH}_{3}$ と なって揮散する)，水溶性のものが水不溶または難溶性になるも の(たとえば過リン酸石灰の水溶性リン酸分である $\mathrm{CaH}_{4}\left(\mathrm{PO}_{4}\right)_{2}$ が，水難溶性の $\mathrm{Ca}_{3}\left(\mathrm{PO}_{4}\right)_{2}, \mathrm{CaHPO}_{4}$ となる) などの不利が起る ので, どの肥料でも勝手自由に混合しうるものでなく, 混合方式が めって（肥料配合図 Mixing chart of fertilizer, Mischungstafel für Düngemittel), なかなかもずかしく自由にならぬる のである。

かようなわけであるが，この点を逝にとらえて，ちる化学肥料 の化学性を知り，その化学性に他の肥料要素を㧠つ化会物を作用 させて一つの化合物の中に 2 種の肥料要素を持たせ，更にその生 成した化合物の化学性に適合する第 3 の肥料要素を持つ化学肥料 を混合し，あるいはそこに，なお化学反応を起させて安定化する よ5にして 2 種， 3 種の肥効要素を適当な割合に含むようにした ものを化成肥料といわれ，最近は複合肥料 (Compound fertilizer, または Combined fertilizer, Complex fertilizer ともい党よう) に統一された。化成肥料は戦前今の日産化学工業怢式会社の前身 の大日本人造肥料時代かに命名（当時同社の苫米地義: 汦による といわれる）されて，もっぱら同社製品名であったようであるが， その後一般にも使用され，戦時中までに非常に盛んとなり数十厅 トンになっていたが，戦後一時はほとんど杜絶えていたものが， この $6 \sim 7$ 年来許可され，急に盛大となり，既に最近では70〜80 万トンを越え 100 万トン台に達して来た。

この华成肥料すなわち複合肥料製造の発端は過リン酸石灰を中 心とし，これに硫酸を配合し，更にその酸性中和にアンモニアを 作用し，これにカリ塩として硫酸カリなどを配合し，むるいはほ とんど作用しない有機質金肥粉末を配合したものも炆初にはあっ たよ5であるが，今では表 6 に示すように，日本での化成，複合 肥料の製造法式の大要を示した。

これで見るように，最初（昭和 25 年頃）は普通の過リン酸石

$\begin{array}{lllllllllll}\text { (A) } & \text { 王 } & 20 \sim 22 & \text { S-P, W-P } & 30,700 & 71.6 & 158,300 & 21.9 & 31,300 & 2.5\end{array}$

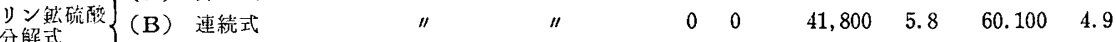

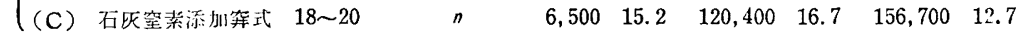

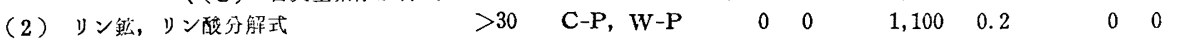

$\begin{array}{lllllllll}\text { (3) リン蚣硝酸 " } & >30 & \text { S-P } & 350 & 0.8 & 800 & 0.1 & 2,600 & 0.2\end{array}$

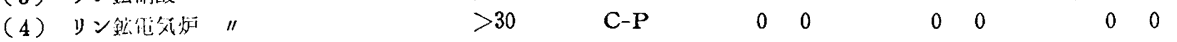

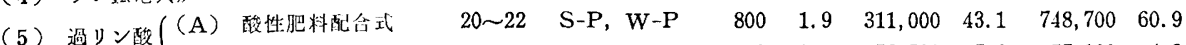
過少配合
牙

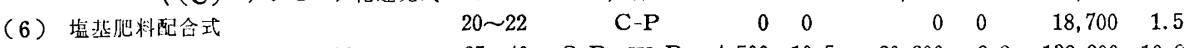

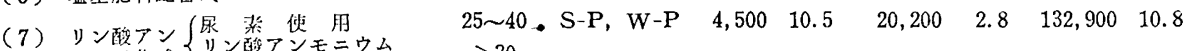

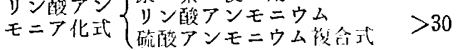

$43,000100.0 \quad 721,000100.01,230,700100.0$

灰の謷造に際し，他の肥效成分化合物を作用させるのが主であっ て，その後も昭和 25 年には增したが，次に過リン酸石灰に他の 肥効成分含有の肥料を配合して行くうj法が急增し，この㞹法とも $\mathrm{N}-\mathrm{P}-\mathrm{K}$ 合㔀は 20〜22\%でこれ以上はこれらのうj汒では增加し難 
いので，他の方法として硫酸に代わる硝概，リン酸などをリン旀 石に作用させる湿式法，リン躴，コークスで電気炉でリンを搏 発させこれを冷却して翼リン，赤リンとして製出し，その一部を 空気酸素で燃やして無水リン酸 $\left(\mathrm{P}_{2} \mathrm{O}_{5}\right)$ とし水に吸収させる方法 で，リン酸液を作る乾式法などでうるリン酸を基としこれにアン モニアを作用して各種りン酸アンモニウム $\left(\mathrm{NH}_{4} \mathrm{H}_{2} \mathrm{PO}_{4},\left(\mathrm{NH}_{4}\right)_{2}\right.$ $\left.\mathrm{HPO}_{4},\left(\mathrm{NH}_{4}\right)_{3} \mathrm{PO}_{4}\right)$ ，これにリン酸に混じている硫酸にアンモニ アが作用して硫陵アンモニウム $\left(\left(\mathrm{NH}_{4}\right)_{2} \mathrm{SO}_{4}\right)$ が混合しているも の，尿素を一部使用することなど，更に硝酸使用で硝酸塩の硝酸 型窒素を含むものなどの各種方法で， N-P-K が 30\% 以上 $40 \%$ にもなる高度化成肥料が近年次第に多くなって来たことは，アメ リカが既に大量の混合, 複合肥料の中 N-P-K の 3 要素合計量も 近年 30\% 以上，40\% 以上から 50\% を越える高度複合肥料の種 類，製造使用量が多種多量になったことは表 7 で明らかである。

㳖 7 米国の混合複合肥料使用量とその成分

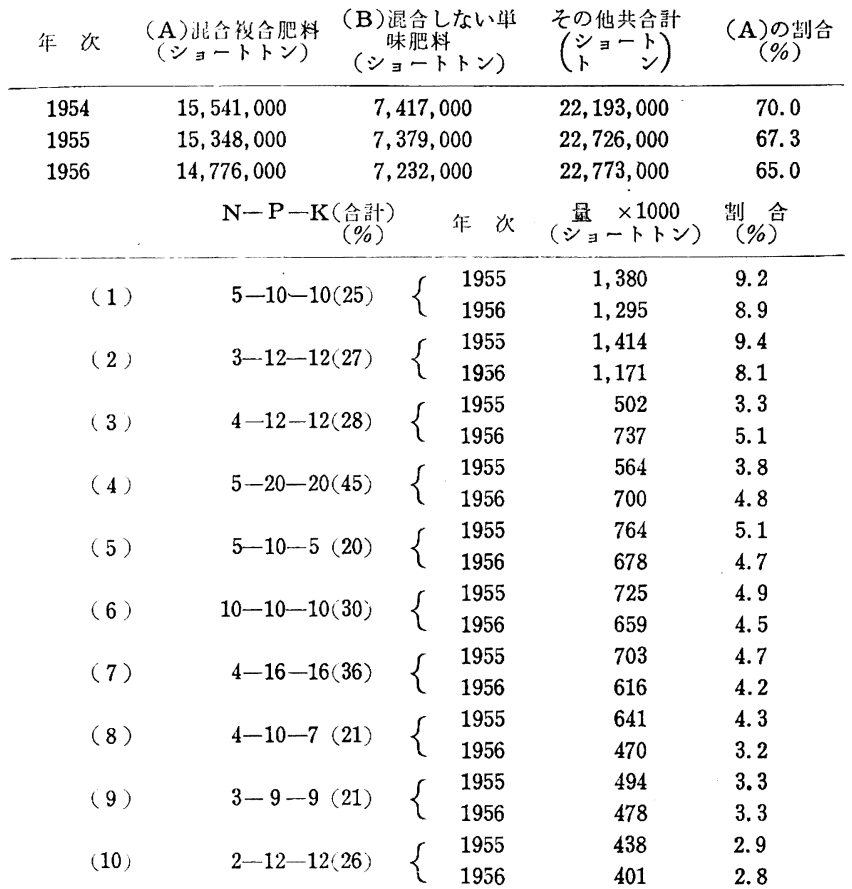

この表で見られるように；アメリカの最近 $(1954 ， 1955,1956$ の 3 年）の混合複合杷料は全体の 65 70\% に達しており，その 中 1955,1956 の 2 年の混合襍合肥料の中 N-P-K 3 要素合計の 多いもの 10 種を学げて見たものでは, 少ないもので 20〜21\%が 3 種, 25〜28\% が 4 種, 30〜36\% が 2 種, $45 \%$ が 1 種である が，いずれを見ても窒素が少なく（2，3，4，5\% が 9 種，10\% の多いのが 1 種)，リン酸が最も多く(9〜12\% が 8 種， 16〜20\% が 2 種)，カリが雨者の中間 $(5 ， 7 ， 9 \%$ が 3 種，10〜12\% が 5 種，16，20\% が 2 種）のよ5にNが少なく，P が最多，K も多 いことは後に掍げる日本の化成，複合肥料とは趣を異にしてい る。なお米国ではこれら混合複合肥料の種類の数は数百種におよ び，ての中 N-P-K の合量の多いものから，上位 176 種の合計 量が 1954 年では約 $15,258 \times 1000$ ショートトンに達し, 全混合複 合肥料の $96.7 \%$ ， 1955 年では約 $14,559 \times 1000$ ショートトンに 達し，96.6\% となるが, 上位 15 種では約 62〜63\%(1954 年 61.7

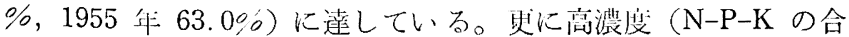
計 $40 \sim 60 \%$ のもの 12 種, 30 39\%のもの3 種）のものは表

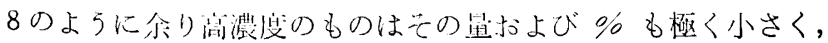

表 8 米国の最高濃度の混合複台肥料

\begin{tabular}{|c|c|c|c|c|}
\hline \multirow{2}{*}{$\mathrm{N}-\mathrm{P}-\mathrm{K}\left(\begin{array}{c}\text { (合晫) } \\
(\%)\end{array}\right.$} & \multicolumn{2}{|c|}{1954 年 } & \multicolumn{2}{|l|}{1955 年 } \\
\hline & (ショ $\stackrel{\text { 量 }}{ }$ トン) & 剣 $(\%)$ & (ショ量 & 割\%) \\
\hline $0-25-25(50)$ & 20 & $<0.005$ & 10,333 & 0.07 \\
\hline $0-30-30(60)$ & 11,055 & 0.07 & 18,623 & 0.12 \\
\hline $6-36-0(42)$ & 556 & $<0.005$ & 3,145 & 0.012 \\
\hline $8-24-12(44)$ & 6,582 & 0.04 & 9,418 & 0.06 \\
\hline $10-20-10(40)$ & 48,714 & 0.32 & 86,642 & 0.58 \\
\hline $10-20-20(50)$ & 9,088 & 0.06 & 15,143 & 0.10 \\
\hline $10-30-10(50)$ & 3,624 & 0.02 & 5,211 & 0.03 \\
\hline $12-24-12(48)$ & 31,354 & 0.21 & 27,327 & 0.18 \\
\hline $14-14-14(42)$ & 2,852 & 0.02 & 33,782 & 0.22 \\
\hline $15-30-0(45)$ & 0 & 0 & 2,958 & 0.02 \\
\hline $20-0-20(40)$ & 4,467 & 0.03 & 7,399 & 0.05 \\
\hline $13-13-13(39)$ & 24,136 & 0.16 & 31,459 & 0.21 \\
\hline $12-12-12(36)$ & 208,922 & 1.37 & 306,858 & 2.04 \\
\hline $10-10-10(30)$ & 701,365 & 4.60 & 725,133 & 4.81 \\
\hline
\end{tabular}

全く試験的で，やはり $30 \sim 36 \%$ 位のものがやや多く，乙かも $\mathrm{N}-\mathrm{P}-\mathrm{K}$ が 10-10-10，12-12-12，13-13-13，14-14-14 のよ5K そろったものが次第に認められ（10-10-10\% のものは年 70〜72 万ショートトン, 全体の 4.6 4.8\%にも達し, ついで 12-12-12 \%のものも 21〜31 万ショートトン, 1.4〜2.0\% に達している), 更に総体として前述のよ5に窒素が少なく，リン酸が最す多く， 30〜36\% に達するものが多いことはやはりこれらの複合肥料が リン酸をリン鈗石から湿式（硫酸溶解）ぬたは乾式（電気炬揮発） のいずれかで製出し，それを台にしてリン酸アンモニウム，リン 酸カリウムなどを主体にして製出されるものが多く，近年この種 の高濃度複合肥料の研究, 試験䡈造を行っているのは例の TVA （テネシー溪谷開拓公社）で次にその $2 ， 3$ の例を表 9 に示そ5。 表 9 米国の濃厚複合肥料の新製品例

(a) TVA 液状過 リン酸 (Super phosphoric acid)

(1) $\left\{\begin{array}{l}\text { Ortho-phosphoric acid, } \mathrm{H}_{3} \mathrm{PO}_{4} \\ \text { Polyphophoric acid, } \mathrm{H}_{x} \mathrm{P}_{y} \mathrm{O}_{z}\end{array}\right.$

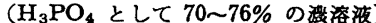
これに

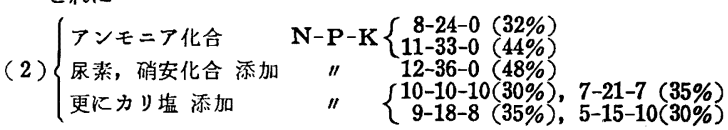

（b） TVA 新激厚肥料

リン酸液に窒奖液（硝安液にアンモニア過䣋吸収により全空素 41 45\%)を加え て母体莈とし，これ㙁化カリ，土㙫調整剂 $\left(\mathrm{MgO}, \mathrm{SiO}_{2}, \mathrm{~B}_{2} \mathrm{O}_{3}\right.$ を含むす の）を配合し，蒸発，乾嬠して粒状化したもの

$$
\text { N-P-K }\left\{\begin{array}{r}
7-28-28(63 \%) \\
17-17-17(51 \%) \\
15-15-15(45 \%) \\
8-16-32(56 \%)
\end{array}\right.
$$

(c) TVA リン酸アンモニウム (Ammonium phosphate)

(1) Meta-ammonium phosphate

メタリン安 $\left(\mathrm{NH}_{4} \mathrm{PO}_{3}\right)\left\{\right.$ 固形状 $\mathrm{N}_{2}+\mathrm{P}_{2} \mathrm{O}_{5} 90 \%$ 慗出困鞠

(2) Di-ammonium phosphate

$$
\left(\mathrm{NH}_{4}\right)_{2} \mathrm{HPO}_{4}\left\{\begin{array}{ll}
\mathrm{N}_{2}: & 21 \% \\
\mathrm{P}_{2} \mathrm{O}_{5}: & 54 \%
\end{array}\right\} \text { 計 } 75 \% \text { p户潮解性大 }
$$

(3) Mono-ammonium phosphate

$$
\mathrm{NH}_{4} \mathrm{H}_{2} \mathrm{PO}_{4}\left\{\begin{array}{ll}
\mathrm{N}_{2}: & 12 \% \\
\mathrm{P}_{2} \mathrm{O}_{5}: & 62 \%
\end{array}\right\} \quad 74 \% \text { 絬晶容易 }
$$

た扎し $[(2)$ と(3) は戦前から独，米などで製出されたアンモホスの主体]

(d) リン化水悲 $\mathrm{PH}_{3}$ (アンモニア $\mathrm{NH}_{3}$ に対等)

$\mathrm{P}: 91 \%, \mathrm{P}_{2} \mathrm{O}_{5}$ 換算 : $208.8 \%$ (約 2.3 倍)

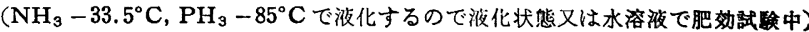

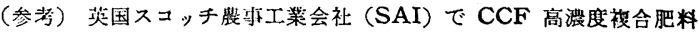
CCF (N-P-K 合就 $40 \%$ 以上)

\begin{tabular}{rccccc} 
& $\begin{array}{c}\mathrm{N}_{2} \\
(\%)\end{array}$ & $\begin{array}{c}\mathrm{S}_{(\%)}-\mathrm{P}_{2} \mathrm{O}_{5} \\
(\%)\end{array}$ & $\begin{array}{c}\mathrm{W}_{(\%)} \mathrm{P}_{2} \mathrm{O}_{5} \\
(\%)\end{array}$ & $\begin{array}{c}\mathrm{K}_{2} \mathrm{O} \\
(\%)\end{array}$ & $\begin{array}{c}\text { N-P-K } \\
\text { 合計(\%) }\end{array}$ \\
\hline $\mathrm{CCF}-1$ & 12.0 & 12.0 & 11.8 & 18.0 & $\mathbf{4 2 . 0}$ \\
$" \prime 2$ & 13.5 & 13.5 & 13.2 & 13.5 & 40.5 \\
$" 3$ & 10.0 & 26.0 & 20.0 & 10.0 & 46.0
\end{tabular}

このように，ほとんど乾式法りン酸を主体とし， $\mathrm{NH}_{3}$, 尿素, 硝安，カリ程などによる複合，混合肥料であり，たたりン化水素 $\left(\mathrm{PH}_{3}\right)$ の肥料化が達成されるか否かが與味があるが，その毒性 
表 10 日本の化成, 複合肥料の生産高, 成分
(A)

\begin{tabular}{|c|c|c|c|c|c|c|c|}
\hline \multirow{2}{*}{ 年 次 } & \multicolumn{3}{|c|}{ 生産高（トン） } & \multicolumn{3}{|c|}{ 平均成分 $(\%)$} & \multirow{2}{*}{$\begin{array}{c}\text { 制 } \\
\mathrm{N}: \mathrm{P}: \mathrm{K} \\
\end{array}$} \\
\hline & $\mathrm{N}_{2}$ & $\mathrm{P}_{2} \mathrm{O}$ & $\mathrm{K}_{2} \mathrm{O}$ & $\begin{array}{ll}\mathrm{N}_{2} & \mathrm{P}_{2} \mathrm{O}\end{array}$ & $\mathrm{D}_{5} \mathrm{~K}_{2} \mathrm{O}$ & 合計 & \\
\hline 和 25 年 & 3,499 & 3,88 & $380 \quad 1,494$ & $8.14 \quad 9.0$ & $03 \quad 3.43$ & 20.60 & $0: 11.1: 4.2$ \\
\hline 26 & 20,103 & 24,08 & $87 \quad 10,008$ & $7.37 \quad 8.5$ & $52 \quad 3.53$ & 19.18 & $: 12$ \\
\hline 27 & 29,780 & 33,7 & $10 \quad 18,422$ & $7.34 \quad 8.3$ & 314.53 & 20.18 & $0: 11.3: 6.2$ \\
\hline 28 & 53,528 & 59,91 & $317 \quad 38,507$ & 7.428 .3 & $31 \quad 5.34$ & 21.07 & $0: 11.2: 7.2$ \\
\hline 29 & 70,218 & 77,22 & 22053,350 & $7.51 \quad 8.2$ & $26 \quad 5.71$ & 21.48 & $11.0: 7.7$ \\
\hline 30 & 88,669 & 93,42 & $127 \quad 66,263$ & 8.008 .4 & $\begin{array}{ll}43 & 5.98\end{array}$ & 11 & $10.5: 7.5$ \\
\hline 31 & 102,763 & 104,14 & 14478,690 & $8.34 \quad 8.4$ & $\begin{array}{ll}46 & 6.39\end{array}$ & 23.19 & $10: 10.1: 7.7$ \\
\hline \multicolumn{8}{|l|}{ (B) } \\
\hline 年 & \multicolumn{2}{|c|}{$\begin{array}{c}\text { 尿类化成系 } \\
(\text { ト }\end{array}$} & $\begin{array}{l}\text { 硫リン安化 } \\
\text { 成系(トン) }\end{array}$ & $\begin{array}{l}\text { リン硝安化 } \\
\text { 成采(トシ) }\end{array}$ & $\begin{array}{l}\text { その他 } \\
\text { (トン) }\end{array}$ & $\begin{array}{l}\text { 弇 計 } \\
(\text { 放) }\end{array}$ & 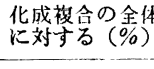 \\
\hline 昭和 26 & \multicolumn{2}{|c|}{4,805} & 6,8 & 1,125 & - & 32 & 4 \\
\hline 27 & \multicolumn{2}{|c|}{11,992} & 9,2 & 1,453 & 1 , & & 6. \\
\hline 28 & \multicolumn{2}{|c|}{45,246} & 9,9 & 803 & 1,650 & 697 & 8.1 \\
\hline 29 & \multicolumn{2}{|c|}{71,121} & 26,17 & 1,493 & 427 & 9,216 & 10.6 \\
\hline 30 & \multirow{2}{*}{\multicolumn{2}{|c|}{$\begin{array}{l}91,539 \\
83,361\end{array}$}} & 77,434 & 1,543 & 4,742 & 258 & 15.7 \\
\hline$\{31$ & & & 132,874 & 2,596 & 631 & 219,461 & 17.8 \\
\hline & \multicolumn{2}{|c|}{$(39.0)$} & $(60.9)$ & $(0.1)$ & 03) & $(100.0)$ & \\
\hline
\end{tabular}

および分解して肥効化の様子が問題であろう。

次に日本の最近の化成, 複合肥料の生産高, 成分と更に N-P-K の合計が $25 \%$ 以上のものとについて表 10 に示したもので見る と昭和 25 年の化成複合肥料製造復興以来急に盛んとなって, 昭 和 31 年は総量 123 万トンとなって来たことは表 6 に示したと拉 りであるが，最初はカリ分が輸入カリ塩使用のため少なく、リン 酸分がやや多く，N-P-K で $10 ： 11 \sim 12 ； 4 ５$ の割合が，次第 飞カリ塩輸入が多くなるにつれて多く，リン酸分をやや減少して $10: 10: 8$ 位となり, 全量です 20〜21\%からやや多く,22２3\% となって来ている。また N-P-K の合計が $25 \%$ 以上の高濃度の すの (30\% 以上 $35 \%, 39 \%$ のbのは極く少量, 極く最近に試作 されていることは表 11 に示す）は硫りン安化成系が 60\%，尿素 化成系が $39 \%$ の 2 種で占め，これに極く少量のリン硝安化成系 があるだけで，結局前記表 7〜9 の米国の例に見るよ5に，リン 酸を基体としてこれにアンモニア，尿素などを作用し，カリ塩配 合によらねばならぬことを示している。ただ日本ではりン酸製造 にほとんど乾式電炉法は極く少なく，多くは湿式硫酸法で，これ はリン酸液の出来るだけ濃い $\left(\mathrm{P}_{2} \mathrm{O}_{5}\right.$ として $30 \%$ 以上) $33 \sim 35 \%$ 位のものを得たいが，副産するセッコウが半水セッコウ $\mathrm{CaSO}_{4}$. $1 / 2 \mathrm{H}_{2} \mathrm{O}$ または無水セッコウ $\mathrm{CaSO}_{4}$ となって, 結晶セッコウ $\mathrm{CaSO}_{4} \cdot 2 \mathrm{H}_{2} \mathrm{O}$ の優良な結晶柱板状で大きい結晶を得ないとリン 酸の口過洗浄にす不便であり, 結晶セッコウをセメント凝結調節
用にリン酸の微量が残って使用不可能，または烧セッコウとして セッコウボード用に硬化強度不足で不適当となって米る。かよう に各種高濃度化成複合肥料製造の基となるリン陵液の製出が，日 本では天然セッコウだけでは不純不足で，その補給のため，この リン酸液製造の副産化学セッコウが年約 10１5 万トン位の製出 が重要視されて，このリン酸セッコウと称し（他の各種の副産化 学セッコウとともに) 重要視されている(1)ように, 湿式法リン酸 液と副産のリン酸セッコウとがともに重要なのは日本だけの問題 である。表 11 のと拈り, 日本ではまだ大体 N-P-K の比が 8:8:7 (7〜10\%: 7〜9\%:5〜7\%) で合計 20〜22\% のものが多く, 30 〜35\% むるいは 39\% の上5に高濃度のものは怊和 30〜31 年か らの試作でもあり, 銘柄数も 1,2 極く少ないもので, 上記米国 には及ばないが，亚通過リン酸石灭が最近きわわて不沉である反 面には，このような高濃度複合肥料への進展が予想され，それに は湿式法硫酸分解式のリン酸液製造とアンモニア, 尿素の使用, 硫リン安, リン硝安などの問題、更に副珄化学セッコウ（リン酸 セッコウ）をセメント，セッコウボードへの使用か，セッコウ梳 安法への原料問題が重要な問題点である。

なおこの化成複合肥料ではほとんどが粒状にされて括り，複合 肥料すなわち粒状肥料の感がある位で，この化学，複合肥料の粒 状化は一つの重要問題となっている。

\section{5）溶成リン肥と焼成リン肥}

リン酸質肥料の大部分を占めていた過リン酸石灰肥料は全リン 酸 $\left(\mathrm{T}-\mathrm{P}_{2} \mathrm{O}_{5}\right)$ 約 $19 \sim 20 \%$ ，水溶性リン酸 $\left(\mathrm{W}-\mathrm{P}_{2} \mathrm{O}_{5}\right)$ 約 $18 \sim 19 \%$ 位 であるが，その主体はリン酸一石灰 $\mathrm{CaH}_{4}\left(\mathrm{PO}_{4}\right)_{2} \cdot \mathrm{H}_{2} \mathrm{O}$ と少量含ま れる遊離りン酸 $\mathrm{H}_{3} \mathrm{PO}_{4}$ とからなるもので, 土壤に施した場合 (1) 土壤中のアルミナと酸化鉄，特に火山灰質の開墾地などの可溶性 アルミナ，酸化鉄の多い畑地（火田）などではこの水溶性リン酸 とアルミナ,酸化鉄との間に作用してリン酸アルミニウム $\mathrm{AlPO}_{4}$, リン酸鉄 $\mathrm{FePO}_{4}$ を生じ, これらが水難溶性（クエン酸には溶け るのでク溶性リン酸 $\left.\mathrm{C}-\mathrm{P}_{2} \mathrm{O}_{5}\right)$ になり，これを過りン酸石灰の戻 り，または劣化, Retrogradation と称し, 甚だしいのは過りン酸 石灭中のリン酸分の約 $1 / 5 ， 20 \%$ 位しかその抬用年中には植物に 吸収されないで，他の大部分 4/5，80\% 住はこの $\mathrm{AlPO}_{4}, \mathrm{FePO}_{4}$ の水難溶性になって翌年以後徐々に土壤中の柏物牌败によって出 来る應植有機酸に溶けて植物に吸上げられる。（2）他の原因は
表 11 日本の化成複合肥料（粒状）の生産割合（\%）と生産量（単位 1000 トン） $\mathbf{N}-\mathbf{P}-\mathbf{K}$ (合計) (\%)

$8-8-5(21)$
$8-7-5(20)$
$6-9-6(21)$
$12-12-9(35)$
$8-7-6(21)$
$8-8-6(22)$
$8-8-8(24)$
$6-12-9(27)$
$7-8-6(23)$
$5-8-5(18)$
$8-6-7(21)$
$15-15-0(30)$
$10-7-6(23)$
$13-13-13(39)$

その他とも合計トン 282,291 昭和25年を 1.0 とする倍率

\begin{tabular}{c}
\hline 昭和 26 年 \\
8.9 \\
0.2 \\
- \\
- \\
- \\
- \\
0.4 \\
- \\
- \\
8.0 \\
- \\
- \\
- \\
282,291 \\
6.6
\end{tabular}

6.6 生应毫合 (\%)

$\begin{array}{rr}24.7 & 24.1 \\ 1.2 & 4.8 \\ - & 0.7 \\ - & - \\ 0.4 & 1.2 \\ 0.8 & 2.8 \\ 0.4 & 1.6 \\ 1.0 & 2.4 \\ - & 1.0 \\ 10.0 & 6.6 \\ - & - \\ - & - \\ - & 1.7\end{array}$

$405,883 \quad 721,435$

9.4
16.8

$\begin{array}{rr}22.6 & 22.5 \\ 7.4 & 9.6 \\ 3.7 & 3.6 \\ - & 1.9 \\ 0.9 & 2.6 \\ 4.8 & 3.6 \\ 1.8 & 2.1 \\ 3.1 & 3.0 \\ 1.4 & 1.9 \\ 6.5 & 3.0 \\ - & 1.8 \\ - & \\ 1.7 & 1.2 \\ - & 0.6\end{array}$

$934,5141,108,486$

$21.8 \quad 25.8$

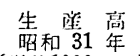
(昭和 31 年

$\begin{array}{rrr}24.0 & 295.0 & 27 \\ 6.6 & 81.3 & 9 \\ 4.5 & 55.1 & 18 \\ 4.1 & 50.3 & 2 \\ 3.8 & 46.6 & 16 \\ 3.3 & 40.1 & 8 \\ 2.8 & 34.8 & 10 \\ 2.5 & 30.4 & 12 \\ 2.4 & 29.5 & 5 \\ 2.4 & 29.4 & 1 \\ 2.3 & 29.0 & 2 \\ 1.7 & 21.3 & 1 \\ 1.5 & 18.3 & 6 \\ 1.4 & 17.4 & 2\end{array}$

過リン酸石灰中に少量残っているフッ 化物（原料りン能石，ことにリン灰石 質のものにはフッ素が $2 \sim 3 \%$ あって これが硫酸液との作用で 70〜60\%は フッ化水素，ヶイ化フッ素として揮散 するが，30４0\% 位は過リン酸石灰 中に残っているもの）が施师後上壤中 の石灰（土壤酸性化の中和に石灭肥料 として消石灭, 焙ドロマイト消化物, 炭カル肥料, 苦土炭カル肥料, その他 ケイカル肥料, 菬上ケイカル肥料, 石 灰窒素などを施すものの不灭）分と 作用して $\mathrm{CaF}_{2}, \mathrm{CaF}(\mathrm{OH})$ となり, $\mathrm{CaH}_{4}\left(\mathrm{PO}_{4}\right)_{2} \cdot \mathrm{H}_{2} \mathrm{O}$ の方もこの石灰でリ ン酸三石灰 $\mathrm{Ca}_{3}\left(\mathrm{PO}_{4}\right)_{2}$, リン酸二不灰 
$\mathrm{CaHPO}_{4} \cdot 2 \mathrm{H}_{2} \mathrm{O}$ となり, これは水難溶性(ク溶性ではあるが)とな り，更に上のフッ化石死と作用してリン灰石化して $3 \mathrm{Ca}_{3}\left(\mathrm{PO}_{4}\right)_{2}$. $\mathrm{CaF}_{2}$ となればいっそう水難溶性となって上記の戻りをいっそう 進めることになる。

かよ5なわけで, 貴重な硫酸液を多量 (ボーメ50 度硫酸, $\mathrm{H}_{2} \mathrm{SO}_{4}$ 62 63\% でリン鉝粉末をほぼ同量）を使用してせっかく 過リン酸石灰の水溶性リン酸 $\left(\mathrm{W}-\mathrm{P}_{2} \mathrm{O}_{5}\right)$ にしたものが，施肥して 大部分がすぐク溶リン酸 $\left(\mathrm{C}-\mathrm{P}_{2} \mathrm{O}_{5}\right)$ になってしまう位なら最初か らク溶成リン酸化合物のリン酸肥料にしておいた方がよい。特に 上述した硫酸根による秋落田の米作の減収を避けるためには，こ の硫酸根を多量に含む過りン酸石灭を避け，をた貴重な硫酸を使 用することを止めて無硫酸根りン酸肥料の聚造使用が，このリン 酸質肥料の重要問題となったのは, あたか子窒素質肥料の硫安に 対するに尿素, 硝安, 塩安, 石灭窒素の上うに, 過リン酸石灰に 対するに溶成リン肥, トーマスリン肥, 焼成リン肥, 脱フッリン 酸三石灰（重過リン陵石灰，リン安などもあるが，ここでは省略 する）のよ5な塩基性で, 款式製造（過りン酸石灰は酸性で湿式 帮造に対抗する）によるものが近年起って来たりン酸肥料界の問 題である。

裴 12 各種リン酸塭, リン酸肥料の比較

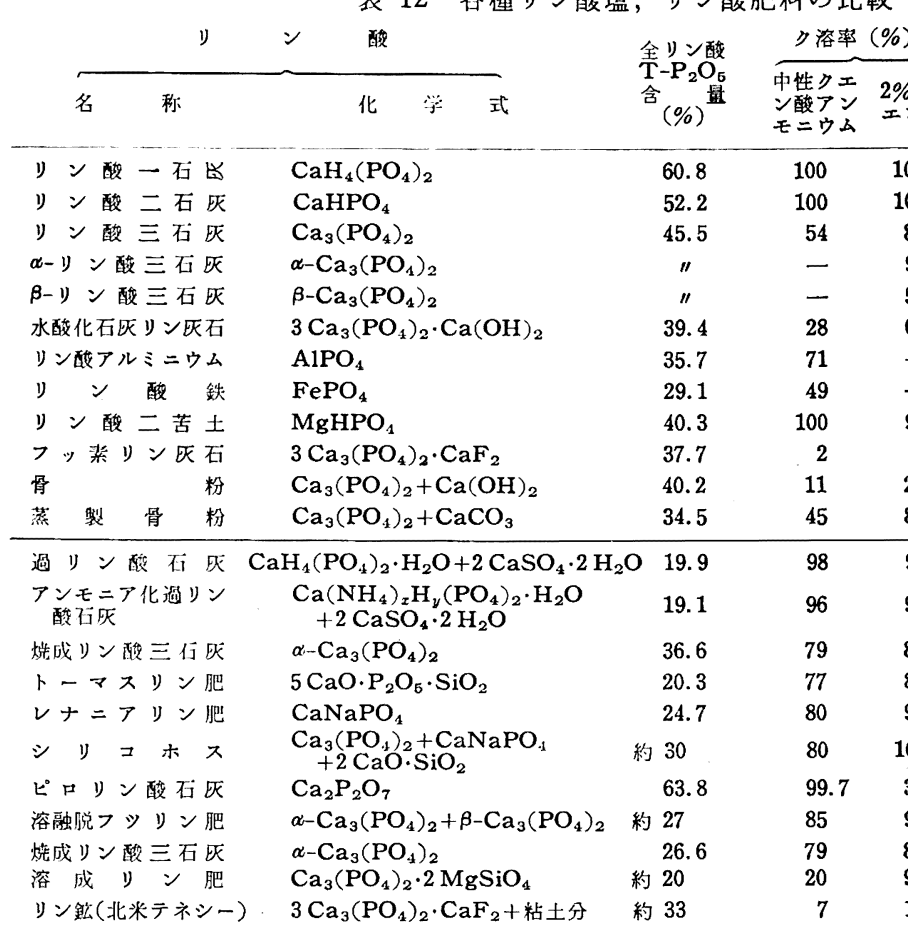

いま, この塩基性乾式製法によるところのリン酸肥料の主体を なす各種リン酸塩のリン酸含有率, リン酸の溶解性, 肥効率などを 表 12 で比較対照してみた。これで知れるよ5に 2 種の溶解液へ の溶解率は中性クェン酸アンモニウムと酸性 $2 \%$ クェン酸とでは 大羑なく, 肥效率も大体この溶解率と平行しており, 乾式製造の各 種リン肥は相当に興味深いもので, 日本の溶成リン肥, 烧成リン肥 などが(近年昭和 $24 \sim 25$ 年以来)急に注目されて年産約 $35 \sim 40$ 万 トンとなり，他のリン酸質肥料(過リン酸石灭)の約 $1 / 5$ 位の製造 高となり，今後も增大されて 60〜70 万トン，過リン酸石圧の約 $1 / 3$ 位にまで発展するのは仡うめずらしくもないことになろう。

次にこれらの乾式製造法について，この大要を 2 分類して表 13 に示した。この種のものとして最も古いものは㹸成リン肥のテト ラリン肥が 1913 年頃イタリアのストッパニが, リン鉱石粉に石
表 13 溶成リン肥と筷成リン肥の分類
溶成りン肥

(I) 溶成リン肥 (Fused phosphate)

(a) トーマスリン肥 (Thomas phosphate)

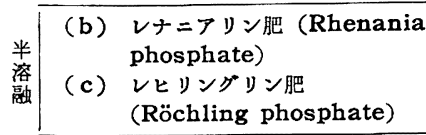

(d) 溶融脱フッリン肥 (Fused phosphate) リン酸三石兏, メタリン酸石灰

（II）溶成苦土リン肥

(a) サーモホス (Thermophos)

(b) ウニワポ (Uniwapo)

(c) 電炉溶融苦土リン肥 (回檕师, 豎㫮, 反射炉)

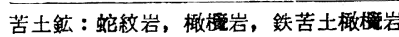

焼成リン肥

(A) 㮱成リン肥 (Calcined phosphate)

(1) テトラリン肥

(Tetra phosphate)
灰石またはドロマイト粉，ボウ硝またはソーダ灰を約 5 10\% 加 光，700 800 焼成によるものであり，レナニアリン肥は 1915 年頃からドイッのカリヘミー社で最初はリン鉱石に石灰石または ドロマイト粉，白榴石または響石などのカリ鉱石粉を加え，1200 $\sim 1300^{\circ} \mathrm{C}$ 飞焼成する焼成リン肥であったが，後にはもっぱらリ ン鉱石にソーダ灰とケイ砂を加え, 十 肥効率 $(\%)$ リン酸一
石灰を 100 として

植木錸試験 ノイパウ

$100 \quad 100$
100 100 86 97 54
64

-

98

98
6

28

81

92

98

87

82

95

100

38

90

87

18
分高い温度で，半溶融から溶融に近い 高温処理の溶成りン肥で, 主成分はレ ナーニット (Rhenanit) と称している $\mathrm{CaNaPO}_{4}$ または $2 \mathrm{CaO} \cdot \mathrm{Na}_{2} \mathrm{O} \cdot \mathrm{P}_{2} \mathrm{O}_{5}$ か

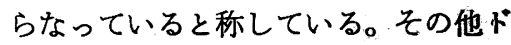
イッのリュベック (Rübeck), ウィポ ルグ(Wiborg), ワザグ (Wasag),ワル テル (Walter) リン肥などはいずれす リン鉱石, ソーダ灰, 褐炭, ケイ础など の配合物を焼成または半溶融式で行引 もので，レナニアリン肥とテトラリン 肥の類似品であるが，いずれる行われ ていないで，ただレナニアリン肥だけ が数十万トンの年産で西独北部キール 運河近くの Brunsbuttelkoog で造 されているのと, レヒリングリン肥 (Röchlingphosphat) が同じく西独マ ンハイム市のヒュッテンヘミー社 (Hütten Chemie) で Röchlingische
Eisen \& Stahlwerke で出来る含硫化ソーダ鉱滓とリン鉱石との 配合物を $1250 \sim 1300^{\circ} \mathrm{C}$ で半溶融ないし溶融製造している 10〜20 万トンとが，いずれる回転炉製造方法で行われている5)。焼成り ン肥の一つのシリコホスフェート（Silico-phosphate）は今次大 戦中,イギリスの国立建築材料研究所で硫酸の不足から過りン酸 石灭慜造の不如意のため，上記ドイッのレナニアリン肥の初期数 造法を追試して，十分基碟的研究から製造に移乃5として実現し なかかったものであるが，膨大な研究試験報告が出され，高ソー ダ型と低ソーダ型のシリコホスフェートがあって, 烧成リン肥の 基礎研究資料である6)。

トーマスリン肥(Thomas phosphate)については, 最も早く起 ったもので, 既に多くの報告, 記述があるので, ここではその方 に譲って省略しまた米国の脱フッリン肥（脱フッリン酸三石 
表 14 溶成リン肥, 筦成リン肥の成分例 (\%)

\begin{tabular}{|c|c|c|c|c|c|c|c|c|c|c|c|c|c|c|}
\hline & 称 & 国 別 & $\mathrm{SiO}_{2}$ & $\mathrm{Al}_{2} \mathrm{O}_{3}$ & $\begin{array}{l}\mathrm{Fe}_{2} \mathrm{O}_{3} \\
(\mathrm{FeO})\end{array}$ & $\mathrm{CaO}$ & $\mathrm{MgO}$ & & $\mathrm{MnO}$ & $\mathrm{T}-\mathrm{P}_{2} \mathrm{O}_{5}$ & $\mathrm{C}-\mathrm{P}_{2} \mathrm{O}_{5}$ & $\mathrm{P}-\mathrm{P}_{2} \mathrm{O}_{5}$ & $\frac{\mathrm{C}-\mathrm{P}_{2} \mathrm{O}_{5}}{\mathrm{~T}-\mathrm{P}_{2} \mathrm{O}_{5}}$ & $\mathrm{~F}_{2}$ \\
\hline & トーマスリン肥 & ドィッ & 9.88 & 3.58 & 8.75 & 47.70 & 3.18 & & 4.95 & 18.25 & 16.86 & - & 92.5 & - \\
\hline & $" \prime$ & ベルギー & 6.98 & 1.38 & $\mathrm{FeO} 9.36$ & 43.70 & 2.68 & & 6.22 & 18.06 & 16.80 & - & 93.0 & 0.03 \\
\hline & $" \prime$ & 西医規格 & $<11$ & - & $<13$ & $40 \sim 50$ & - & & - & - & $>15$ & - & - & - \\
\hline & $n$ & 日本 & 8.30 & 1.37 & 9.47 & 47.24 & 3.74 & & 6.22 & 19.37 & 17.21 & - & 89.0 & - \\
\hline & $" \prime$ & $" \prime$ & 7.48 & 1.93 & 6.99 & 49.76 & 2.77 & & 5.65 & 20.62 & 19.99 & - & 96.8 & 一 \\
\hline & レヒリングリン肥 & ドィッ & 19.83 & 4.10 & $\mathrm{FeO} 3.00$ & 32.00 & 3.60 & $\mathrm{Na}_{2} \mathrm{O}$ & 12.90 & 19.81 & - & 18.60 & $(93.9)$ & 0.30 \\
\hline & レナニアリン肥 & ドイッ & 10.54 & 1.58 & 0.71 & 40.05 & 一 & $\mathrm{Na}_{2} \mathrm{O}$ & 15.43 & 29.09 & - & 28.00 & $(96.3)$ & 2.19 \\
\hline & $" \prime$ & $"$ & 12.43 & 1.37 & 0.59 & 42.08 & - & $\mathrm{Na}_{2} \mathrm{O}$ & 12.65 & 24.70 & 23.62 & 23.35 & $\begin{array}{c}94.4 \\
(94.1)\end{array}$ & 2.40 \\
\hline & 溶成リン酸三石长 & アメリカ & 20.61 & 5.83 & 2.24 & 40.60 & 0.75 & & - & 28.65 & 23.00 & - & 80.3 & 0.32 \\
\hline & 焼成リン酸三石艮 & アメリカ & 48.65 & 0.56 & 0.87 & 28.83 & - & & - & 20.55 & 19.56 & 18.58 & 95.1 & 0.02 \\
\hline & シリコホス & イギリス & 10.5 & & 6.0 & 42.0 & 1.2 & $\mathrm{Na}_{2} \mathrm{O}$ & 12.2 & 28.0 & 27.5 & 一 & 98.5 & - \\
\hline & $" \prime$ &. & 11.0 & & 6.7 & 41.5 & 0.8 & $\mathrm{Na}_{2} \mathrm{O}$ & 14.5 & 25.5 & 24.0 & - & 94.0 & - \\
\hline & サーモホス & アメリカ & 24.7 & 3.0 & 3.2 & 31.3 & 15.3 & & - & 20.3 & 19.6 & - & 96.5 & - \\
\hline & $\prime \prime$ & $"$ & 22.41 & 1.57 & 4.28 & 33.12 & 16.83 & & - & 21.01 & 19.00 & - & 90.5 & 1.50 \\
\hline & 溶成(苦土) リン肥 & 日本 & 23.44 & 1.78 & 3.61 & 33.12 & 16.83 & & - & 21.20 & 21.03 & - & 99.1 & 1.50 \\
\hline & $" \prime$ & $" \prime$ & 27.87 & 2.44 & 2.83 & 33.68 & 14.28 & & - & 19.78 & 19.61 & - & 99.2 & 1.15 \\
\hline . & $" \prime$ & $"$ & 24.87 & 1.71 & 5.07 & 28.09 & 21.82 & & - & 18.61 & 18.47 & - & 99.4 & - \\
\hline & $"$ & $"$ & 24.25 & 6.18 & 3.92 & 28.00 & 17.82 & . & - & 20.66 & 20.40 & - & 98.7 & 0.52 \\
\hline & $n$ & " & 29.21 & 2.36 & 4.46 & 30.54 & 17.41 & & - & 19.04 & 19.00 & - & 99.8 & - \\
\hline & $\prime \prime$ & $"$ & 24.64 & 1.57 & 4.99 & 33.31 & 17.90 & & - & 19.51 & 18.98 & - & 97.3 & - \\
\hline & $"$ & $"$ & 25.30 & & 5.04 & 34.85 & 15.55 & & - & 18.20 & 17.87 & - & 98.32 & - \\
\hline & 姺成リン肥 & 本 & 10.17 & & 2.71 & 40.41 & - & $\mathrm{Na}_{2} \mathrm{O}$ & 9.03 & 37.28 & 35.0 & - & 94.2 & - \\
\hline & " & $n$ & 8.42 & 1.23 & 0.59 & 40.02 & - & $\mathrm{Na}_{2} \mathrm{O}$ & 10.5 & 38.23 & 33.52 & - & 92.4 & - \\
\hline & 重姺成 リン肥 & 本 & 5.61 & 0.93 & 0.82 & 27.41 & - & $\mathrm{Na}_{2} \mathrm{O}$ & 7.72 & 43.11 & 41.22 & - & 95.6 & -- \\
\hline
\end{tabular}

灰, メッン酸石灰)などについてはアメリカでの試験研究の報告 があるが, 肥料よりも飼料用としての脱フッ処理も大切のようで あるし，またこの脱フッリン肥工業は余り振わなく，かつ肥料よ り飼料的研究試験が多いので，ここでは省き，以下もっぱら溶成 （苦土）リン肥, 焼成リン肥について略述し, 詳しいことは, 前 記5)牤よび下記7)の参考文献に詳しいので，それに譲り，表 14 に 各種の溶成リン肥, 焼成リン肥の試料の成分分析例を示した。こ の結果を見ると， $\mathrm{T}-\mathrm{P}_{2} \mathrm{O}_{5}$ は多くは 18～20\%，中には 28〜29\% 位のすのが多く, 中には $\mathrm{T}-\mathrm{P}_{2} \mathrm{O}_{5}$ は $18 \sim 20 \%$ 位が特に多く, $\mathrm{T}-\mathrm{P}_{2} \mathrm{O}_{5}$ が 26〜28\% のもので, C- $\mathrm{P}_{2} \mathrm{O}_{5}$ は $\mathrm{T}-\mathrm{P}_{2} \mathrm{O}_{5}$ よりはやや 少なく, レナニアリン肥，シリコホスフェート，日本の焼成リン 肥, 重焼成リン肥は概して $\mathrm{T}-\mathrm{P}_{2} \mathrm{O}_{5}$ が $12 \sim 15 \%$ ，日本の焼成お よび重焼成りン肥には $\mathrm{Na}_{2} \mathrm{O}$ 含有量はな拈少なく 8〜10\% 位で

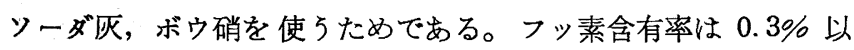
下位のすの, $1.2 \sim 1.5 \%$ 位の溶成リン肥, $2.2 \sim 2.4 \%$ 位のレナ ニアリン肥などになるが，この脱フッの問題と水流急冷の問題と が溶成リン肥と焼成リン肥との分れ目で，焼成リン肥では急冷は 必ずしも必要ではないが，脱フッは出来れば $0.1 〜 0.2 \%$ 以下で ないとク溶性リン酸が增さないし, ク溶率 $\left(\left(\mathrm{C}-\mathrm{P}_{2} \mathrm{O}_{5}\right) /\left(\mathrm{T}-\mathrm{P}_{2} \mathrm{O}_{5}\right)\right.$ の\%) が高い 95〜98\% のよろな優良のものにならない（この焼 成リン肥製造に水蒸気により脱フッされた廃ガスからフッ素を石 灰などで $\mathrm{CaF}_{2}$ として回収し，製鉄，セメント製造またはフッ化 物製造原料にする)。これに対し溶成リン肥は脱フッは必要条件 ではない（普通の溶成苦土リン肥ではフッ素が約 $1.2 \sim 1.5 \%$ 位 残っており，レナニアリン肥では上揭表 14 の例のように 2.2〜 $2.4 \%$ も残って扣り，普通の溶成苦土リン肥の製造では原料りン 鉣石のフッ素分の約 30〜50\% は脱フッされるので，この場合も 水流急冷の蒸気, 電気炉廃ガスなどからフッ素分を $\mathrm{CaF}_{2}$ として 回収することも行われる）が，水流急冷して非結晶性ガラス化が ク溶性リン酸分, 従ってク溶率を高めることに必要である。

\section{6） マグネシア化過リン酸石灰}

上述の溶成リン肥がアメリカでサーモホス（Thermophos）と
して戦後いち早く日本にも紹介され, それと相前後して試験研究 され, 昭和 $24 \sim 25$ 年から本格的製造に進み, 急速に発展し, 最 近では年産約 40 万トン（能力は約 65 万トン余）に達したのは, 窒素質肥料中の尿素が約 30 万トン，塩安が約 20 万トンといず れも戦後 10 年間以内で発達した 3 種の新興化学肥料で, 硫安に対 する無硫酸根肥料, 過リン酸石灰に対する無硫酸根肥料として溶 成リン肥が重用されたが，も5一つの理由は表 14 に見るように， 溶成リン肥は唯一のマグネシア含有量の多い ( $\mathrm{MgO}$ 約 $15 \sim 20 \%)$ リン肥であるから，今日のようなマグネシア欠乏土壌のマグネシ ア補給に役立つので過りン酸石灰が到底対抗出来ないという点で ある。この過リン酸石灰に何とかして，マグネシアを含ませよ5 として考案されたのが，ここに述べようとするマグネシア過リン 酸石灰である。

その最初の考案は国内各地にある蛇紋岩 $3(\mathrm{Mg}, \mathrm{Fe}) 0 \cdot 2 \mathrm{SiO}_{2}$. $2 \mathrm{H}_{2} \mathrm{O}$ は $\mathrm{MgO}$ 約 35 40\%, $\mathrm{SiO}_{2}$ 約 35 40\%, $\mathrm{FeO}$ と $\mathrm{Fe}_{2} \mathrm{O}_{3}$ 約 $8 \sim 10 \%$, 結合水約 $12 \sim 15 \%$ 位，その他 $\mathrm{CaO}, \mathrm{Al}_{2} \mathrm{O}_{3}$ など $2 \sim 5$ \%以内のものが多く, 土石で有用な鉣石扱いされないもので，き わめて安価なもので, 最近前述の溶成リン肥製造用に重要視され その以前には岩綿の製造原料に使用された位の用途しかなかった ものである。この蛇紋岩の微粉末を過りン酸石死に対し約 15〜 $17 \%$ 位，すなわち過リン酸石灰：蛇紋岩を約 6〜7:1（6:1〜 $7: 1$ ）位の割合に均一に配合したものが蛇紋過リン酸（詳しくは

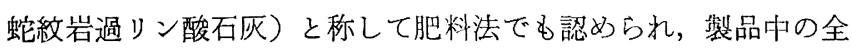
リン酸 $\left(\mathrm{T}-\mathrm{P}_{2} \mathrm{O}_{5}\right) 15 \%$ 以上, 水溶性 リン酸 $\left(\mathrm{W}-\mathrm{P}_{2} \mathrm{O}_{5}\right) 1 \%$ 以 上, 全マグネシア $(\mathrm{T}-\mathrm{MgO})$ 約 5〜6\% 以上, ク溶性マグネシア (C-MgO) 3.5\% 以上とい5ことが規定してある。

この蛇紋過りン酸は蛇紋岩の風化の程度, 過りン酸石灰の酸性 度，水分などによって混合したものは直ちに，または比較的早く 作用して過リン酸石灰の主要な水溶性リン酸分を蒋成する $\mathrm{CaH}_{4}$ $\left(\mathrm{PO}_{4}\right)_{2} \cdot \mathrm{H}_{2} \mathrm{O}$ なり, 少量の遊離リン酸分 $\mathrm{H}_{3} \mathrm{PO}_{4}\left(3 \mathrm{H}_{2} \mathrm{O} \cdot \mathrm{P}_{2} \mathrm{O}_{5}\right)$ の 水溶性リン酸分は, 蛇紋岩のマグネシアの一部水溶性のものと作 用して3 種のリン酸マグネシウムの $\mathrm{MgH}_{4}\left(\mathrm{PO}_{4}\right)_{2}$ リン酸一マグ 
表 16 マグネシア化過 リン酸石灰の成分例（\%)

\begin{tabular}{|c|c|c|c|c|c|c|c|c|c|c|c|}
\hline $\begin{array}{l}\text { 過りン酸石戻: マ } \\
\text { グネシア掹原料 }\end{array}$ & $\begin{array}{l}\text { 配分後の } \\
\text { 期 间 }\end{array}$ & 水分 & $\mathrm{T}-\mathrm{P}_{2} \mathrm{O}_{5}$ & $\mathrm{C}-\mathrm{P}_{2} \mathrm{O}_{5}$ & $\mathrm{~W}-\mathrm{P}_{2} \mathrm{O}_{5}$ & $\begin{array}{l}\mathrm{C}-\mathrm{P}_{2} \mathrm{O}_{5} \\
\mathrm{~T}-\mathrm{P}_{2} \mathrm{O}_{5}\end{array}$ & $\frac{W-P_{2} O_{5}}{T-P_{2} O_{5}}$ & $\mathrm{~T}-\mathrm{MgO}$ & $\mathrm{C}-\mathrm{MgO}$ & $\frac{\mathrm{C}-\mathrm{MgO}}{\mathrm{T}-\mathrm{MgO}}$ & $\mathrm{pH}$ \\
\hline \multirow{3}{*}{ 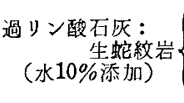 } & 0日亘後 & 15.0 & 15.23 & 14.51 & 11.31 & 95.3 & 74.2 & 7.18 & 0.66 & 9.2 & 4.2 \\
\hline & 30 & 9.9 & 15.30 & 14.60 & 3.75 & 95.4 & 24.5 & 7.23 & 6.22 & 86.0 & 5.9 \\
\hline & 60 & 9.3 & 15.33 & 14.66 & 3.69 & 95.6 & 24.1 & 7.21 & 6.25 & 86.6 & 5.9 \\
\hline \multirow{3}{*}{$\begin{array}{c}\prime \prime \\
\text { 怪㜔ドロマイト } \\
\text { (水 } 10 \% \text { 添加) }\end{array}$} & 0 & 15.1 & 15.21 & 14.58 & 7.57 & 95.6 & 52.8 & 4.33 & 3.05 & 70.4 & 5.2 \\
\hline & 30 & 9.0 & 15.24 & 14.63 & 2.24 & 96.0 & 14.6 & 6.96 & 4.51 & 90.6 & 6.0 \\
\hline & 60 & 8.8 & 15.20 & 14.80 & 2.21 & 97.1 & 14.0 & 6.98 & 4.58 & 92.0 & 6.1 \\
\hline \multirow{3}{*}{$\begin{array}{l}\text { 過リン酸石厑 : } \\
\text { 烧成蛇紋岩 }\end{array}$} & 0 & 6.7 & 15.67 & 14.92 & 14.79 & 95.2 & 94.1 & 7.86 & 3.05 & 38.8 & 一 \\
\hline & 30 & 6.0 & 15.55 & 14.95 & 10.05 & 95.9 & 64.6 & 7.41 & 5.05 & 68.2 & - \\
\hline & 60 & 6.0 & 16.01 & 15.08 & 8.76 & 94.2 & 54.7 & 7.35 & 5.23 & 71.2 & 一 \\
\hline \multirow{3}{*}{ 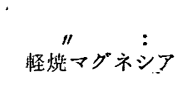 } & 0 & 6.6 & 16.72 & 14.74 & 2.91 & 88.4 . & 17.4 & 12.01 & 10.91 & 90.3 & - \\
\hline & 30 & 5.1 & 15.99 & 15.18 & 1.88 & 94.9 & 11.8 & 12.03 & 10.80 & 89.6 & 一 \\
\hline & 60 & 4.3 & 15.81 & 15.02 & 1.93 & 95.3 & 11.5 & 12.30 & 11.01 & 87.6 & - \\
\hline \multicolumn{2}{|c|}{ 蛇紋過 リン酸の規定 } & & $>15$ & & $>1$ & & & $>5 \sim 6$ & $>3.5$ & & \\
\hline
\end{tabular}

ネシウム (水溶性リン酸), リン酸二マグネシウム $\mathrm{MgHPO}_{4}$ (? 溶性リン酸), リン酸三マグネシウム (ク溶性リン酸) $\mathrm{Mg}_{3}\left(\mathrm{PO}_{4}\right)_{2}$ へと変化 ${ }^{8)}$ して元の配合原料過リン酸石灰の水溶性 リン酸分が 16〜17\%から多いのは 19２0\%に達するものが，僅か 15～17\% の蛇紋岩粉を加えるだけで化合して次第に $\mathrm{MgO}$ が多い中性化ま たは弱塩基性への变化が急に起るため，水溶性リン酸は $>1 \%$ と いら急低下してしまうといらのが論議される点である。

この蛇紋岩の生のものの外，約 $700 \sim 800^{\circ} \mathrm{C}$ 位に蟙成したもの について子試験研究され，その外筆者む蛇紋岩の生扣よび烧成物， ドロマイトをそのままあるいは焼成し，ドロマイト微粉，ドロマ イトを 700 800 ${ }^{\circ} \mathrm{C}$ で焼成した後水で消化した苦土石灰肥料とな るもの，これを海水，カン水，苦汁液に作用して水酸化マグネシ ウムを多量に作り，これを海水マグと略称し，この海水マグその まま，またはこれを約 $800^{\circ} \mathrm{C}$ 位に軽く焼いた軽烧マグネシア(軽 焼マグと略称）など種々のものを約 15〜20\% 位過りン酸石灰に 配合した各種のマグネシア化過リン酸石灰（マグネシア化と称す るのは上述のように，また次の諸表のように，これらのマグネシ ア含有物を配合すると急速汇水溶性りン酸分が急減し，ク溶性り ン酸は增減が少なくマグネシアの水溶性, ク溶性にも変化が起る よ5に化学反応が起って過りン酸石灰にマグネシアが入って各種 のリン酸マグネシウムが出来ることは表 15 のよ5に想定されて いるので，マグネシア化過リン酸石灰と称した）の種々の場合の 配合例とそのマグネシア化過りン酸石灰の成分，ことに水溶性， ク溶性リン酸分，マグネシアの成分，その溶解性などについて筆

表 15 マグネシア分による過りン酸石灰中のリン酸塩の変化

（1）避離りン酸からリン酸ーマグネシアヘ

$\mathrm{MgO}+x \mathrm{H}_{3} \mathrm{PO}_{4}+y \mathrm{H}_{2} \mathrm{O} \longrightarrow \mathrm{MgH}_{4}\left(\mathrm{PO}_{4}\right)_{2} \cdot 2 \mathrm{H}_{2} \mathrm{O}$

$$
\text { 水溶性 } \text { 水溶性 }
$$

（2）リン酸一石灰からリン酸一マグネシウムとりン酸二石灰へ $\mathrm{MgO}+x\left[\underline{\mathrm{CaH}_{4}\left(\mathrm{PO}_{4}\right)_{2}} \cdot \mathrm{H}_{2} \mathrm{O}\right]+y \mathrm{H}_{2} \mathrm{O} \longrightarrow$ 水溶性

$$
\frac{\mathrm{MgH}_{4}\left(\mathrm{PO}_{4}\right)_{2}}{\text { 水溶性 }_{\text {ク溶性 }}} \cdot 2 \mathrm{H}_{2} \mathrm{O}+\mathrm{CaHPO}_{4} \cdot 2 \mathrm{H}_{2} \mathrm{O}
$$

（3）リン酸一石灰からリン酸二マグネシウムとリン酸二石灰 $\mathrm{MgO}+x\left[\mathrm{CaH}_{4}\left(\mathrm{PO}_{4}\right)_{2} \cdot \mathrm{H}_{2} \mathrm{O}\right]+y \mathrm{H}_{2} \mathrm{O} \longrightarrow$

$$
\frac{\mathrm{MgHPO}_{4} \cdot 3 \mathrm{H}_{2} \mathrm{O}}{\eta \text { 溶性 }}+\frac{\mathrm{CaHPO}_{4} \cdot 2 \mathrm{H}_{2} \mathrm{O}}{\eta \text { 溶性 }}
$$

（4）リン酸一マグネシウムからリン酸二マグネシウムへ $\mathrm{MgO}+\frac{\mathrm{MgH}_{4}\left(\mathrm{PO}_{4}\right)_{2}}{\text { 水溶性 }} \cdot 2 \mathrm{H}_{2} \mathrm{O}+y \mathrm{H}_{2} \mathrm{O}=\frac{\mathrm{MgHPO}_{4} \cdot 3 \mathrm{H}_{2} \mathrm{O}}{\text { ク溶性 }}$

者が最近陚験 ${ }^{9)}$ した結果の一部を表 16 に示した。

また表 17 には別に石灭窒素, 尿素などの塩基性窒素肥料, 溶 成リン肥，烧成リン肥などの中性，塩基性リン酸肥料，塩化カ
表 17 塩基性複合粒状肥料の成分例

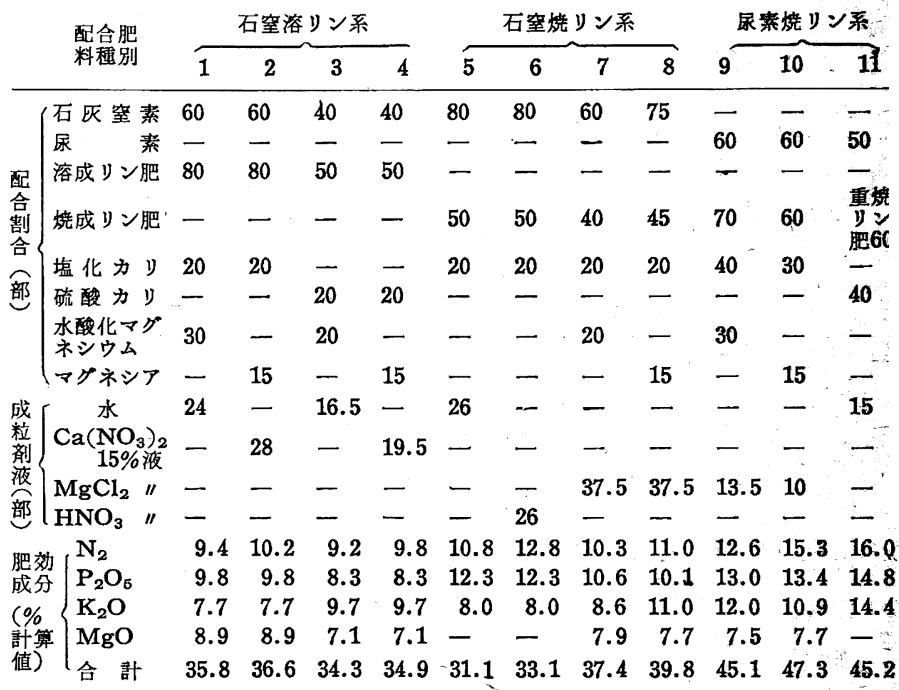

リ，硫酸カリなどの中性カリ肥料，それに海水水酸化マグネシウ ムをたはマグネシアのような塩基性マグネシア分とをいずれす粉 末状で配合し，これを水または $15 \%$ 溶液の成粒剤を溶液の状態 で加光て回転円筒法で 1 1.5 mm 以下の粒にして，その各配合 肥料の間に少しは起るはずの化学反応のため，また成粒物の乾燥 中, 貯蔵中の化学反応によって肥効要素の変化（石灰窒素中のシ アナミド窒素の一部がジシアンジアミド，アンモニアなどにな り, 溶成リン肥, 焼成リン肥中の リン酸分がク溶性から 難溶性 への変化など）を来たすか否かを試験研究報告10して拉り，この 種特殊複合肥料にマグネシアを $7 \sim 9 \%$ 位を加えると, $\mathrm{N}_{2}+\mathrm{P}_{2} \mathrm{O}_{6}$. $+\mathrm{K}_{2} \mathrm{O}$ の 3 要素で約 30 33\% 位のものが, 約 37〜45\% 位の 4 成分含有の濃厚化学肥料となり，マグネシア欠乏土壤に好適なる のとなろう。筆者らは更にこの成粒剤にホウ酸塩，モリブデン酸 塩を少量加えて $\mathrm{B}_{2} \mathrm{O}_{3} 2 \sim 3 \%, \mathrm{MoO}_{3} 0.2 \sim 0.3 \%$ を含み, 更に $\mathrm{ZnO}, \mathrm{MnO}, \mathrm{CuO}$ などもそれぞれの塩類として加えて, 微量要 素 (肥効第 3 要素) の数種を含むものまで試作研究中である。

\section{7）結語}

化学肥料が窒素質の硫安, リン酸質の過リン酸石灰, カリ質の硫 酸カリの第 1 要素の 3 大単味肥料の重要性の地位は今日でも変わ りはないが, 第 2 要素の石灰，マグネシア，ケイ酸，第 3 要素の 微量要素などの問題，単味に対する配合，化成または複合肥料で しかも要素含有率の高濃度, 耕土培養（秋落田, 火山灭質土壤） 問題など種くの問題から来る化学肥料の本質的榆討によって，最 
近はこの硫安, 硫酸カリとともに過リン酸石灰もリン酸肥料界の 王座にゆるぎはないが，種々の多くの問題点が重積して来ている ことにかんがみ, リン酸肥料問題について論じた。その主要点を 摘録して見ると，

（1）リン酸の水溶性必ずしも第 1 意義要点ではなく，ク溶性 リン酸が考慮され, 溶成リン肥, 焼成リン肥, トーマスリン肥, レナニアリン肥, その他種々の乾式製法によるリン酸肥料が起り, リン酸分だけでなくク溶性のマグネシア，ヶイ酸などの第 2 要素 を含み，第 3 要素をも含み 5 る乾式リン酸肥料が問題となった。

（2）耕土培養, 秋落水田, 火山灰質土壤のため無硫酸根肥料 の必要性のため, 硫安に対する尿素, 塩安, 硝安, 硫酸カリに対 する塩化カリと同じに過リン酸石灰に対する溶成リン肥, 焼成り ン肥, トーマスリン肥などの乾式りン酸肥料が，同時にマグネシ ア,ヶイ酸などをもその化合相手として，しかもク溶性の形で含 むリン酸肥料が問題となった。

（3）酸性肥料が多量の中和用石灰を必要とし，更に貴重な硫 酸を多量に土㖶に残して酸性化，秋落水田その他の原因となるの に対し，塩基性または中性肥料を推賞することから溶成りン肥， 㜔成リン肥，トーマスリン肥，その他がこれに答えるリン酸肥料 としての問題となった。

（4）粉状，吸湿性肥料よりも粒状肥料が問題となり，次の項 の複合肥料問題と相俟って複合肥料といえば粒状肥料，また粒状 肥料といえば複合肥料となり，この化成複合肥料の製出に石灰窒 素が使用不適当であったが，同じ塩基性の烧成リン肥，溶成リン 肥を用い,これに中性の塩化カリなどによって無硫酸根粒状複合 肥料製出の可能性が考えられる。

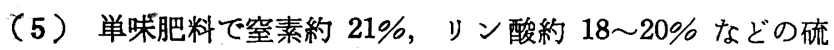
安, 過りン酸石灰よりす配合, 化成, 複合肥料で窒素, リン酸, カリの 3 要素を大体 $10: 9: 8 \sim 10: 10: 10$ 位の割合に含み, し かも普通の配合肥料ではこの 3 要素合計が約 $18 \sim 22 \%$ 位のもの が多かったが, 次の高度化成複合肥料のよ5に次第に多く，25〜 28\% から 30\%を越えるすのに向って来た。

(6) 窒素, リン酸, カリの 3 要素を $30 \%$ 以上 $40 \%$, 中には 40〜 $50 \%$ の高濃度に含有する高級複合肥料はまずリン酸をリン 鉣石から乾式（電炉またはガス炉の揮発式）または湿式（硫酸， 硝酸などの溶解式)で製出し，これにアンモニア，尿素などを化 合させたものを中心として, カリ塩を配合し，あるいは硝安をる 配合するなどの方式を採り, 硫酸による溶解法の湿式法が日本で はすっぱら採用され，その時副産するセッコウがセメント用，セ ッゴウボード用, セッコウ硫安法などに関連して問題となって来 ている。

（7）肥効第 1 要素の窒素, リン酸, カリの外に第 2 要素の石 灰, マグネシア,ケイ酸の 3 要素の中, 特にマグネシアとケイ酸と の欠乏土壤への補給が重要となり, 水溶性マグネシウム塩の外, ク溶性のマグネシア，ヶイ酸などを含むものが電気炉，高炉など のスラグのケイカル肥料, 苦土ケイカル肥料よりも溶成りン肥の ようにリン酸, マグネシア, 石灰, ケイ酸の 4 成分をほとんど 15 〜20，25３0\%の範囲に均衡のとれた形で含むものが，日本では 急速にこの 7〜8 年間に年 40 万トンの域にまで発達し, 蛇紋過 リン酸石灰の上うにその対抗策に過リン酸石灰の援助策として出 た嫌いがあるが, 過リン酸石灰の製造に多量の硫酸(ボーメ50度
硫酸で過リン酸石灰の量の約半分, 従って日本では年䄪 100 万卜 ン, 従って全硫酸の約 $20 \%$, 硫安用の約 $45 \%$ とともに硫安, 過 リン酸石灰の三つで約 $65 \%$ 以上の大部分の硫酸使用) を使用し て，水溶性リン酸の $\mathrm{CaH}_{4}\left(\mathrm{PO}_{4}\right)_{2}$ リン酸一石灰を作りながら，蛇 紋岩のマグネシアの作用で配合して数日で氷溶性リン酸が激減し て数\%となり，ク溶性リン酸のリン酸二石灰， $\mathrm{CaHPO}_{4}$, リン酸 二マグネシウム $\mathrm{MgHPO}_{4}$ にしてしま5不得策が見られる。

（8）この第 2 要素，第 3 要素を単に第 1 要素肥料に配合する だけでなく，化合状態などに含ませる特殊複合肥料の製出には溶 成リン肥，焼成リン肥に含ませるか，それらを中心にして化成複 合肥料とするか，または上記（6)のよ5にリン酸夜を製出し，こ れに第 2 ，第 3 要素のあるものを化合させたものを中心して，他 を補 万配合，化成複合肥料を製出するような方法で，第 1 ，第 2 ， 第 3 の合計 12 要素 (1) $\left(\mathrm{N}_{2}, \mathrm{P}_{2} \mathrm{O}_{5}, \mathrm{~K}_{2} \mathrm{O},(2) \mathrm{CaO}, \mathrm{MgO}, \mathrm{SiO}_{2}\right.$, (3) $\left.\mathrm{Fe}_{2} \mathrm{O}_{3}, \mathrm{ZnO}, \mathrm{CuO}, \mathrm{MnO}, \mathrm{B}_{2} \mathrm{O}_{3}, \mathrm{MoO}_{3}\right)$ を出来るだけ多く 含ましめる微量要素含有特殊複合肥料の製出も考えられる。

以上, 数点を摘記したよ5にリン酸質肥料も窒素質肥料と同じ よらに，あるいはそれ以上に最近の化学肥料界に打いては，その 製造はもとより，施用の方面にも重要問題となって来たよ5に思 われる。リン酸肥料は独立に考えるべきでなく，窒素肥料と相共 に車の両輪のごとく, これにカリ肥料, 石灰, マグネシア, ケイ 酸の第 2 要素, 更に第 3 要素の酸化マンガン, ホウ酸, 酸化モリ ブデン，更に必要ならば酸化亜鉛以下をもあわせ载せた宝の車と して文化生活, 国力繁栄のため豊富な食糧, 植物性工業原料の増 産確保の礎となら权ばなら奴ものと信ずる。

一文献一

1）鈴木，佐藤，東工試報 $50 ， 125$ (1955).

2）鈴木, 中川, 武井, 佐藤, 東工試報 48, 57 (1953); 50 , 207, 217 (1955).

3) 永井, 石膏と石灰 No. 17, 3 (1955); No. 22, 1 (1956); No. 30, 3 (1957).

4) 永井, 石膏 No. 3, p. 4(1951); 同, No. 4, p. 4(1952); 同, No. 5, p. 2(1952); 石哲と石灰 No. 9, p. 1 (1954); 同, No. 30, p. 1 (1957); 同, No. 35, p. 26 (1958).

5) 永井彰一郎, 安藤淳平, 「溶成りン肥と焼成りン肥」, 肥料 第 9 集 (1954).

6) "The Production and Agricultural Value of Silicophosphate Fertilizer", Monograph, No.11-108, Ministry of Supply, Shell Mix House, Strand, London, W.C. 2.

7) 木村, 「溶成 (烧成)リン肥工業」化学々工業 Vol. 8, No. 1, p. 23(1955); 安藤淳平, 「溶成リン肥, 焼成リン肥の工 業化学的研究」学位諭文.

8) 中村, 山添, 岸本, 「過りン酸石灰々蛇紋岩との反応に関す る研究」(第 $1 \sim 2$ 報), 日本土腋肥料学会誌 25 , No. 2, p. $61 \sim 64 ; 25$, No. 5, p. 191 193 (1955); 同上,（第 3 $\sim 4$ 報), 農業技術研究所, 化学肥料部化学科, 昭和 30 年 3 月 (1955).

9）永井, 藤谷, 巴川, 「蛇紋岩, 檄㰖岩, ドロマイト又は水 マグと過リン酸石灰によるマグネシア質過リン酸石灰の研 究」, 工化 $61 ， 940 \sim 942$ (1958); 永井, 荒井「ドロマイ トによる過リン酸石灰のマグネシア化反応」, 石高と石灰 No. 36, 9〜19 (1958); 永井, 大島, 色川, 「海水マグネシ アによるマグネシア化過リン酸石灰」, 日本塩学会誌 11 , $314 \sim 322$ (1957).

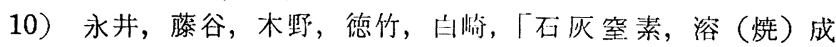
リン肥,カリ塩による粒状特殊複合肥料の研究」工化 61, 1128〜1133 (1958). 